\title{
Comparison and Modal Analysis of Christmas Carols That is Read in Syrian Orthodox and Greek Orthodox Temples In Istanbul
}

Ayșegül Arslan, M. Safa Yeprem *

* İTÜ Geliştirme Vakfi Okulları, **Marmara Üniversitesi

E-mail: aysegul86arslan@gmail.com*, syeprem@gmail.com**

Copyright (C) 2015 Ayşegül Arslan, M. Safa Yeprem. This is an open access article distributed under the Eurasian Academy of Sciences License, which permits unrestricted use, distribution, and reproduction in any medium, provided the original work is properly cited.

\begin{abstract}
There are a lot of similarities between muslim and non-muslim congregations' temple musics in Istanbul. But this cultural inheritance is not easy to be reached and collected for researchers. In this article, christmas carols of Syrian and Greek Orthodox church which are the old congregations of İstanbul have been analyzed and compared.

Keywords: Christmas carols, Syrian Carols, Greek Carols, Orthodox Carols

\section{İstanbul'daki Süryani Ortodoks ve Rum Ortodoks Mabetlerinde Okunan Doğuş İlahilerinin Makamsal Analiz ve Karşılaştırması ${ }^{1}$}

\section{ÖZET}

İstanbul'da yaşayan müslüman ve gayr-i müslim cemaatlerin mabed müziklerinde pek çok benzerlik vardır. Ancak bu kültürel mirasın tespit edilmesi kolay değildir. Bu makalede, İstanbul'un iki kadim cemaati olan Süryani ve Rum Ortodoksların kiliselerinde "Noel"de okunan ilahiler analiz edilerek karşılaştırılmaktadır.

Anahtar Kelimeler: Doğuş ilahisi, Süryani ilahileri, Rum İlahileri, Ortodoks ilahileri

\section{Giriş}

İstanbul, Doğu Roma Bizans İmparatorluğu döneminde Hristiyanlığın (Ortodoksluk), ardından Osmanlı döneminde de İslam dininin (özellikle hilafet açısından) önemli bir merkezi olmuştur. Yüzyıllarca bu coğrafyada yaşayan semavi din mensupları, inançları göz önünde bulundurulduğunda birbirlerinden farklılıklar ortaya koysalar da kültürel manada pek çok benzerliklere sahiptir. Safa Yeprem, yaptığ çalışmada (Yeprem, 2004: s.311, 314, 316, 323, $324,325,326,327,329,330,331,334)$ günümüz İstanbul'undaki bu cemaatlerin müziklerinde Kaside, Dua, Na't, Mevlid, İlahi ve Miraciye formlarıyla "işlevsel manada" değerlendirmeler yapmış, bular arasında bir takım benzerlikler ve farklar tespit etmiş̧tir. Biz bu çalışmada, Süryani Ortodoks ve Rum Ortodoks kiliselerinde, peygamberin doğuşunun kutlandığı gün

\footnotetext{
${ }^{1}$ Makale, Marmara Üniversitesi İlahiyat Fakültesi İslam Tarih ve Sanatları Anabilim Dalı, Türk Din Musikisi Bilim Dalı'nda Ayşegül Arslan'ın “Semavi Dinlerin İstanbul'daki Mabetlerinde İcra Edilen Doğuş İlahilerinin Karşılaştırmalı Analizi” (2015) isimli yüksek lisans tezi kaynak alınarak yazılmıştır.
} 
okunan ilahilerin makamlarını mercek altına alarak onların birbirlerine ne dereceye kadar benzerlik ve farklar ortaya koyduklarını ortaya koymayı amaçladık.

\subsection{Problem Durumu}

Dini musiki alanında semavi dinleri konu alarak yapılan karşılaştırmalı çalışmaların çok az olması nedeniyle bu alanda akademik çalışma yapılması gereği hissedilmiştir. Yapılan çalışmalarda da bu eserlerin makam, usul, güfte analizleri gibi teknik detaylarına yeterince yer verilmemiş olması, bir problem olarak kabul edilebilir. Bu problemin üzerine gidilmesi ile alana dair daha fazla bilgiye ulaşılabileceği düşünülmektedir.

\subsection{Problem cümlesi}

Süryani Ortodoks ve Rum Ortodoks Kiliselerinin İstanbul'daki mabetlerinde peygamberin doğuşunun kutlandığı gün söylenen ilahilerin makamsal özelliklerine dair benzerlik ve farklar nelerdir?

\subsection{Hipotez}

Süryani Ortodoks ve Rum Ortodoks Kiliselerinin makamsal özellikleri birbirine benzemektedir.

\subsection{Alt Problemler}

1.4.1 Tespit edilen ilahilerde ton ya da makam ortaklığı var mıdır?

1.4.2 İlahilerin ses aralığında benzerlik var mıdır?

1.4.3 İlahilerde geçki yapılan cins ya da makamlarda benzerlik var mıdır?

1.4.4 Karar sesi kullanımında benzerlik var mıdır?

1.4.5 Yeden sesi kullanımı var midır?

1.4.6 İlahilerin nihâî karar seslerinde kalış durumlarında (tam kalış-asma kalış) benzerlik var midir?

1.4.7 Ortakl1kları tespit edilen hüseyni, hicaz, uşşak, saba, rast, segâh, nihavent, acem, hüzzam, acemaşiran makamlarının (Yeprem, 2004: s. 311) seyir özellikleri arasında ilişki var mıdır?

\subsection{Metodoloji}

Konu ile ilgili farklı verilerin ortaya çıkmasıyla (özellikle yapılacak karşılaştırmalarda) daha farklı sonuçlara ulaşılması mümkündür. Araştırmada kullanılacak veriler "alan araştırması" "na bağlı "kişisel görüşmeler" ve "kaynak tarama" yöntemleriyle bir araya getirilmiş, bu veriler daha sonra "analiz", "karşılaştırma" yöntemleriyle işlenmiştir. Araştırmanın bu yönüyle betimsel bir çalışma olduğu söylenebilir.

Elde edilen veriler benzerlik ve farklara göre sınıflandırılıp yukarıda belirtilmiş olan yöntemlerle bir araya getirilmiştir. Benzerlik ve farkların ortaya konulacağı bulgular ayrı bir başlıkta ele alınmış, daha sonra ayrı bir bölümlerde bu bulguların önce analizleri sonra da karşılaştırmaları yapılmıştır. Sonuç bölümünde ise karşılaştırmaları yapılan bütün istatistiksel verilerin 1şı̆̆ında ulaşılan noktalar ortaya konulmuştur. 


\subsection{Sinırlamalar}

Araştırmada elde edilen veriler ve bunlara bağlı olarak yapılacak yorumlar, ulaşılabilen kaynaklarla sınırlıdır. Çalışmada kullanılan makam sınırlamaları önceden ortaklıkları tespit edilmiş olan, uşşak, segâh, saba, nihavent, rast, hüseyni, hüzzam, acem, hicaz ve acemaşiran makamları (Yeprem, 2004: s. 311) öncelikli olmak üzere ulaşılabilen beşer eserle sınırlandırılmıştır. Doğaçlama okunan doğuş konulu ilahiler de makale alanının dışında bırakılmıştır.

\subsection{Varsayımlar}

- Arel-Ezgi-Uzdilek makam sisteminin doğru olduğu ve Türk müziği alanını bütünüyle ifade ettiği,

-Görüşülen kaynak kişilerden derlenen bilgilerin doğru olduğu, bu kişilerin cemaatleri temsil ettiği varsayılmaktadır.

\subsection{Evren ve Örneklem}

Araştırmanın evrenini, Müslümanlık, Hristiyanlık (Ermeni Ortodoks, Ermeni Katolik, Süryânî Ortodoks, Keldânî Katolik, Alman Latin Katolik, Presbiteryen, Protestan) ve Yahudilik dinlerine mensup cemaatler oluşturmaktadır.

Örneklemimizi; İstanbul'da yaşayan, mabede ve kalabalık cemaate sahip, liturjisinde tek sesli müzik kullanan ve ulaşılabilen şu dinlerin cemaatleri kapsayacaktır:

\subsubsection{Süryânî Kadîm Kilisesi cemaati}

1.8.2. Fener Rum Patrikhanesine bağlı Rum Ortodoks Kiliseleri cemaati

\section{Makamsal Özelliklere Ait Bulgular}

$\mathrm{Bu}$ bölümde ilahilerin ton/makamlarının ne olduğu, ses aralıklarının dizi içinde gösterimi, seyir sırasında yaptıkları geçkilerin neler oldukları, karar seslerinin ne olduğu, ilahinin bitiminde yeden kullanımı olup olmadığı, varsa yeden sesinin ne olduğu gösterilecektir. Makamsal olan ilahilerin ayrıntılı seyir analizi ölçü ölçü gösterilecektir.

İlahilerin ses alanını gösterebilmek için her eserin dizisi oluşturulmuştur. Türk müziğinde konu olan makamın dizisi de verilerek derlenen ilahilerin rahatça karşılaştırma yapılması hedeflenmiştir. Türk müziğgi dizileri İsmail Hakkı Özkan'1n "Türk Mûsikisi Nazariyatı ve Usulleri” kitabıyla paralel olan Tanburî Murat Aydemir'in "Türk Müziği Makam Rehberi” kitabından alınmıştır.

İlahilerin makamsal analizini yapmamda yardım eden Sayın Dr. Başak İlhan Harmancı hocama teşekkürü borç bilirim. 


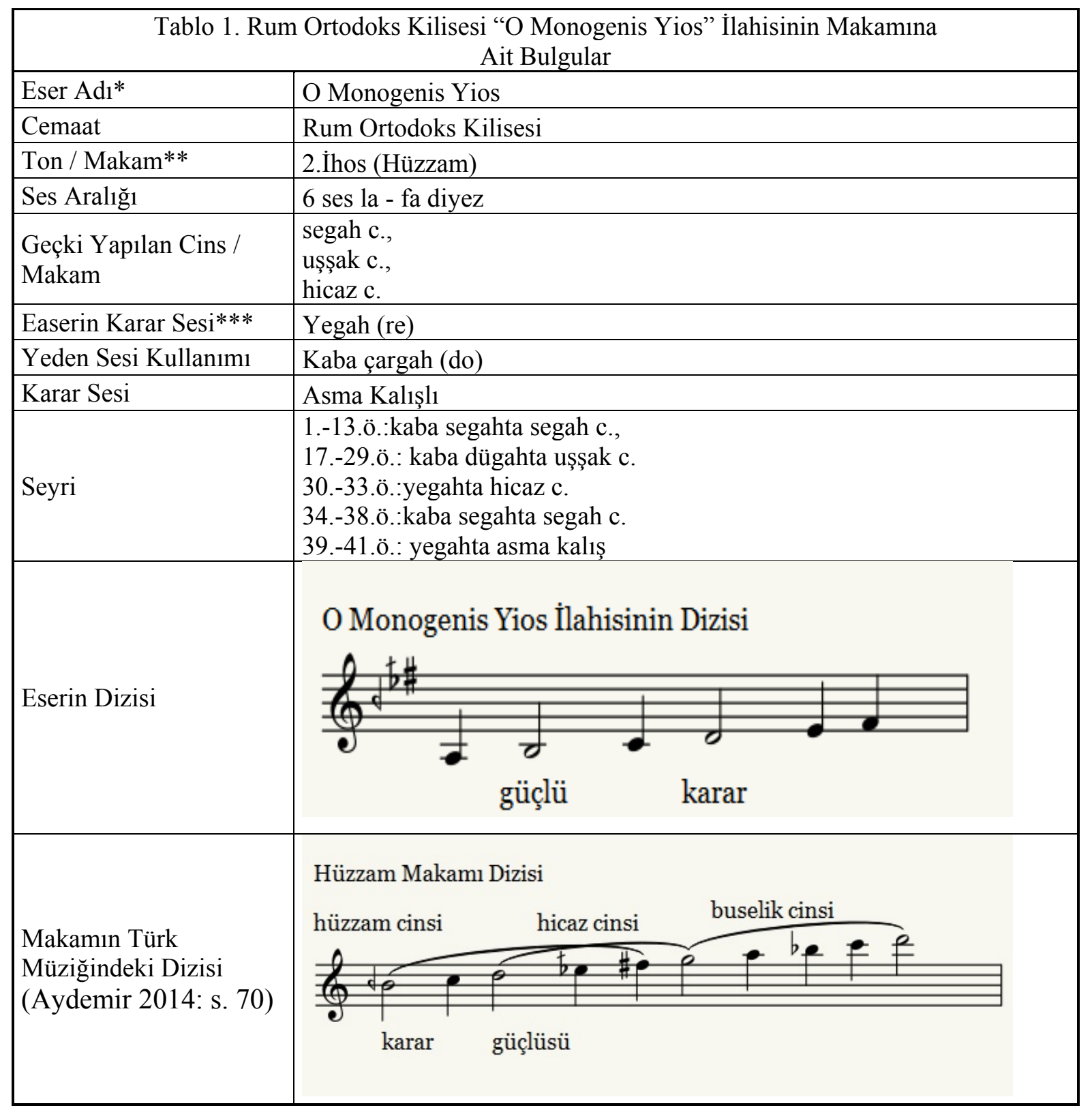

(Bakınız Ek 1)

\footnotetext{
*Eser, Aya Triada Kilisesi koro şefi Panteleimon Zafeiris’ten derlenmiştir.

** Eserin ton/makam bilgisini Panteleimon Zafeiris vermiştir.

***Eserin karar sesi bilgisi Panteleimon Zafeiris’ten alınmıştır.
} 
Tablo 2. Rum Ortodoks Kilisesi "I Genesis Sou” İlahisinin Makamına Ait Bulgular

\begin{tabular}{|c|c|}
\hline Eser Ad1* & I Genesis Sou \\
\hline Cemaat & Rum Ortodoks Kilisesi \\
\hline Ton / Makam** & 4.İhos (Segah) \\
\hline Ses Aralığ & \begin{tabular}{|l}
7 ses \\
la diyez- sol \\
\end{tabular} \\
\hline $\begin{array}{l}\text { Geçki Yapılan Cins / } \\
\text { Makam }\end{array}$ & $\begin{array}{l}\text { hicaz c., } \\
\text { uşşak c., } \\
\text { segah c. }\end{array}$ \\
\hline Easerin Karar Sesi*** & segah (si) \\
\hline Yeden Sesi Kullanımı & Yok \\
\hline Karar Sesi & Tam Kalışlı \\
\hline Seyri & $\begin{array}{l}\text { 1.-2. ö. : güçlü ses ile seyre başlamış, } \\
\text { 3.-4.ö.: nevada hicaz c., } \\
\text { 5. ö. Segahta segah c., } \\
\text { 7.-8.ö.: nevada hicaz c., } \\
\text { 9.ö.: segahta segah c., } \\
\text { 10.-14. ö., nevada hicaz c., } \\
\text { 15.-16.ö.: segahta segah c., } \\
\text { 17.-18. ö. : dügahta uşşak c., } \\
\text { 19.-24.ö.: nevada hicaz c., } \\
\text { 25.ö.:segahta segah c. }\end{array}$ \\
\hline Eserin Dizisi & $\begin{array}{l}\text { I Genesis Sou İlahisinin Dizisi } \\
\text { karar }\end{array}$ \\
\hline $\begin{array}{l}\text { Makamın Türk } \\
\text { Müziğindeki Dizisi } \\
\text { (Aydemir 2014: s. 59) }\end{array}$ & Segah Makamı Dizisi \\
\hline
\end{tabular}

(Bakınız Ek 2)

*Eser, Aya Triada Kilisesi koro şefi Panteleimon Zafeiris’ten derlenmiştir.

** Eserin ton/makam bilgisini Panteleimon Zafeiris vermiştir.

***Eserin karar sesi bilgisi Panteleimon Zafeiris’ten alınmıştır. 
Tablo 3. Rum Ortodoks Kilisesi "Xristos Genatai" (a) İlahisinin Makamına Ait Bulgular

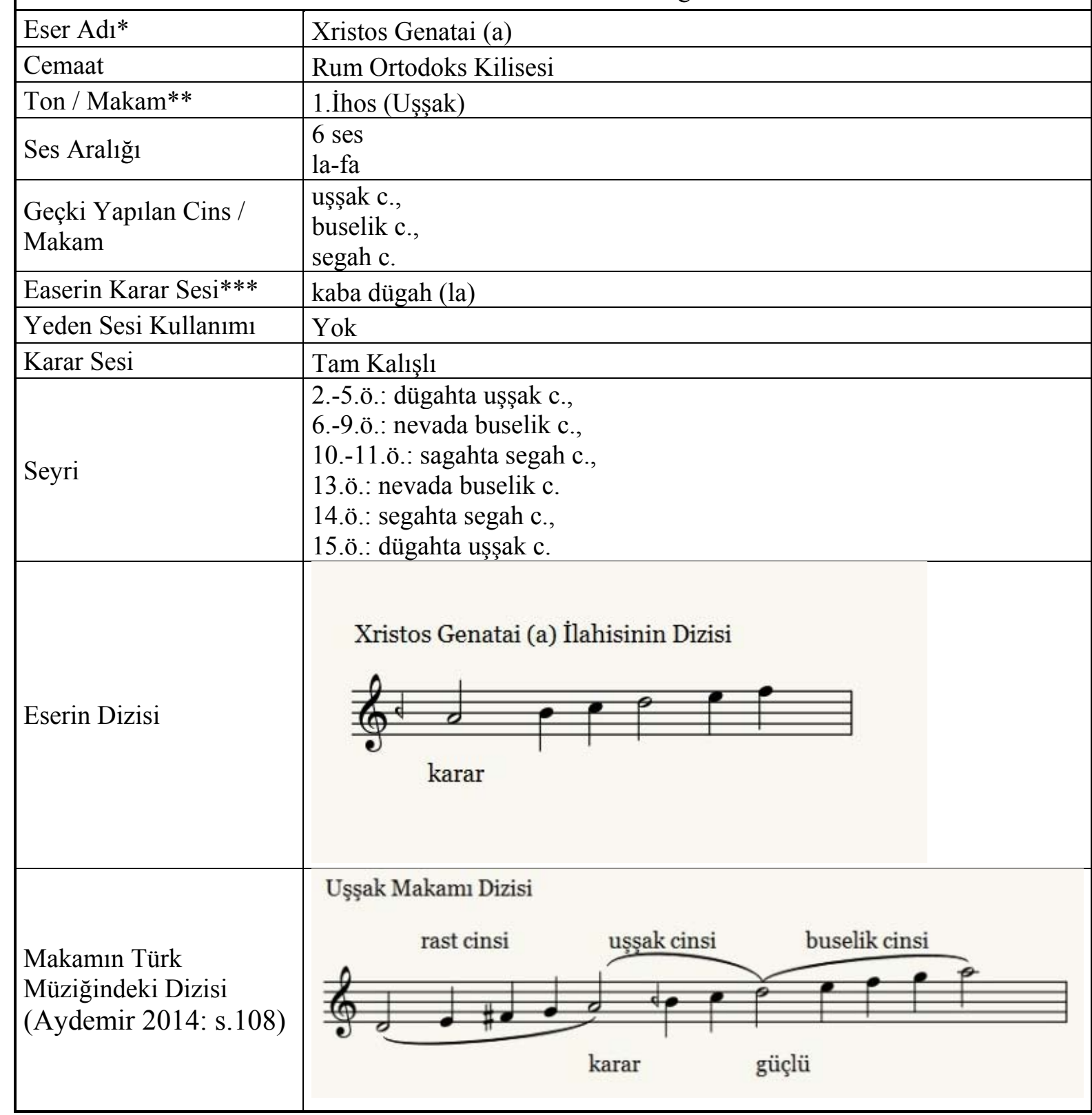

(Bakınız Ek 3)

*Eser, Aya Triada Kilisesi koro şefi Panteleimon Zafeiris’ten derlenmiştir.

** Eserin ton/makam bilgisini Panteleimon Zafeiris vermiştir.

***Eserin karar sesi bilgisi Panteleimon Zafeiris’ten alınmıştır. 
İstanbul'daki Süryani Ortodoks ve Rum Ortodoks Mabetlerinde Okunan Doğuş İlahilerinin Makamsal Analiz ve Karşılaştırması

Tablo 4. Rum Ortodoks Kilisesi "Xristos Genatai" (b) İlahisinin Makamına Ait Bulgular

\begin{tabular}{|c|c|}
\hline Eser Ad1* & Xristos Genatai (b) \\
\hline Cemaat & Rum Ortodoks Kilisesi \\
\hline Ton / Makam** & 1.İhos (Uşşak) \\
\hline Ses Aralığ & $\begin{array}{l}10 \text { ses } \\
\text { sol-si }\end{array}$ \\
\hline $\begin{array}{l}\text { Geçki Yapılan Cins / } \\
\text { Makam }\end{array}$ & $\begin{array}{l}\text { uşşak c., } \\
\text { rast c., } \\
\text { segah c., } \\
\text { buselik c. } \\
\end{array}$ \\
\hline Easerin Karar Sesi*** & Kaba buselik (si) \\
\hline Yeden Sesi Kullanımı & Yok \\
\hline Karar Sesi & Tam Kalışl1 \\
\hline Seyri & $\begin{array}{l}\text { 1.-9.ö.: kaba buselikte uşşak c., } \\
\text { 10.-14.ö.: hüseyni aşiranda rast c. } \\
\text { 15.-17.ö.: kaba buselikte uşşak c. } \\
\text { 18.-20.ö.: kaba rastta segah c. } \\
\text { 21.-23.ö.: hüseyni aşiranda buselik c. } \\
\text { 24.-27.ö.:kaba buselikte uşşak c. } \\
\text { 28.-38.ö.: kaba buselikte uşşak c. }\end{array}$ \\
\hline Eserin Dizisi & Xristos Genatai (b) İlahisinin Dizisi \\
\hline $\begin{array}{l}\text { Makamın Türk } \\
\text { Müziğindeki Dizisi } \\
\text { (Aydemir 2014: s.108) }\end{array}$ & Uşşak Makamı Dizisi \\
\hline
\end{tabular}

(Bakınız Ek 4)

\footnotetext{
*Eser, Aya Triada Kilisesi koro şefi Panteleimon Zafeiris’ten derlenmiştir.

** Eserin ton/makam bilgisini Panteleimon Zafeiris vermiştir.

***Eserin karar sesi bilgisi Panteleimon Zafeiris’ten alınmıştır.
} 
Tablo 5. Rum Ortodoks Kilisesi "Hristos Anesti"

İlahisinin Makamına Ait Bulgular

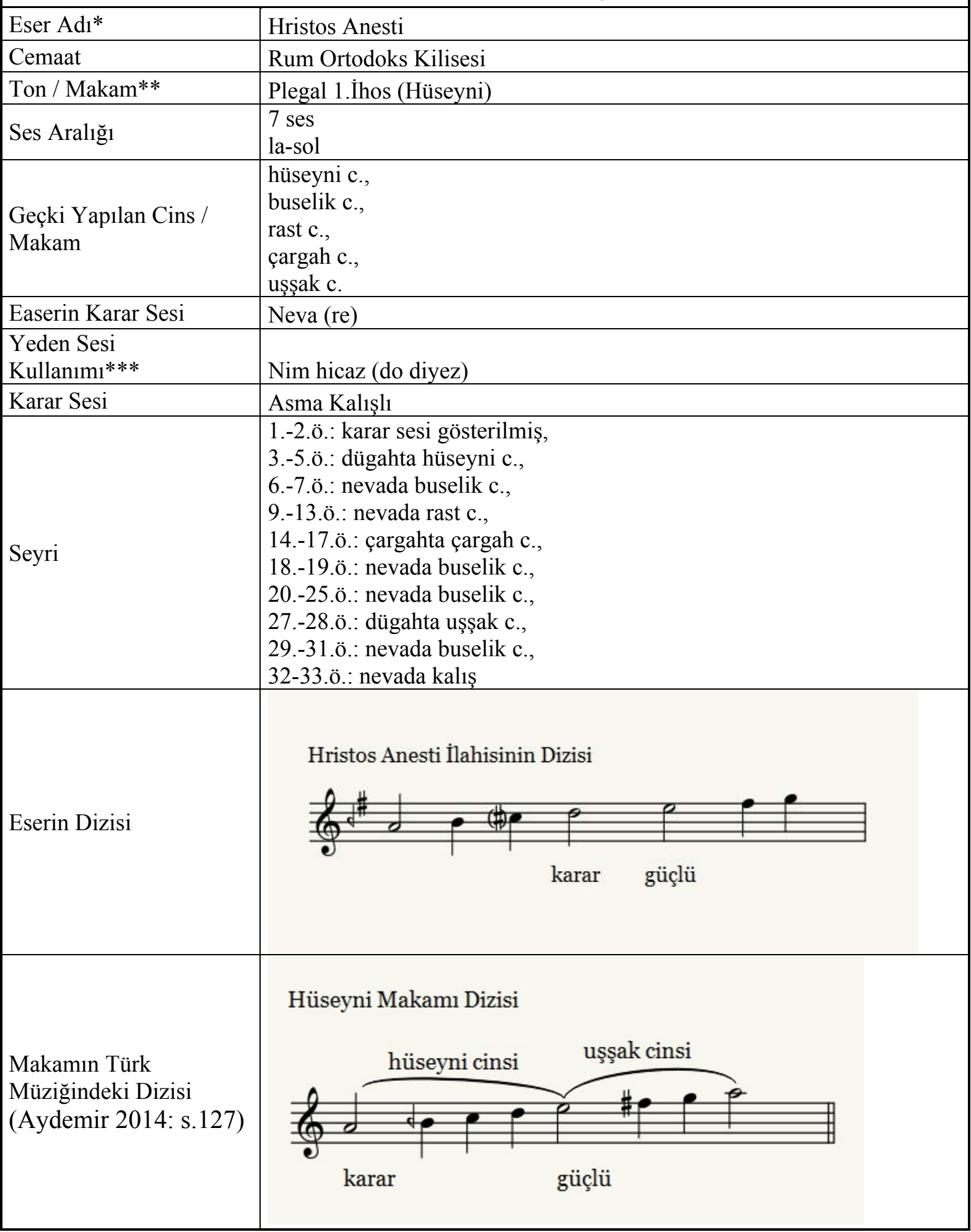

(Bakınız Ek 5)

*Eser, Aya Triada Kilisesi koro şefi Panteleimon Zafeiris’ten derlenmiştir.

** Eserin ton/makam bilgisini Panteleimon Zafeiris vermiştir.

***Eserin karar sesi bilgisi Panteleimon Zafeiris’ten alınmıştır. 
İstanbul'daki Süryani Ortodoks ve Rum Ortodoks Mabetlerinde Okunan Doğuş İlahilerinin Makamsal Analiz ve Karşılaştırması

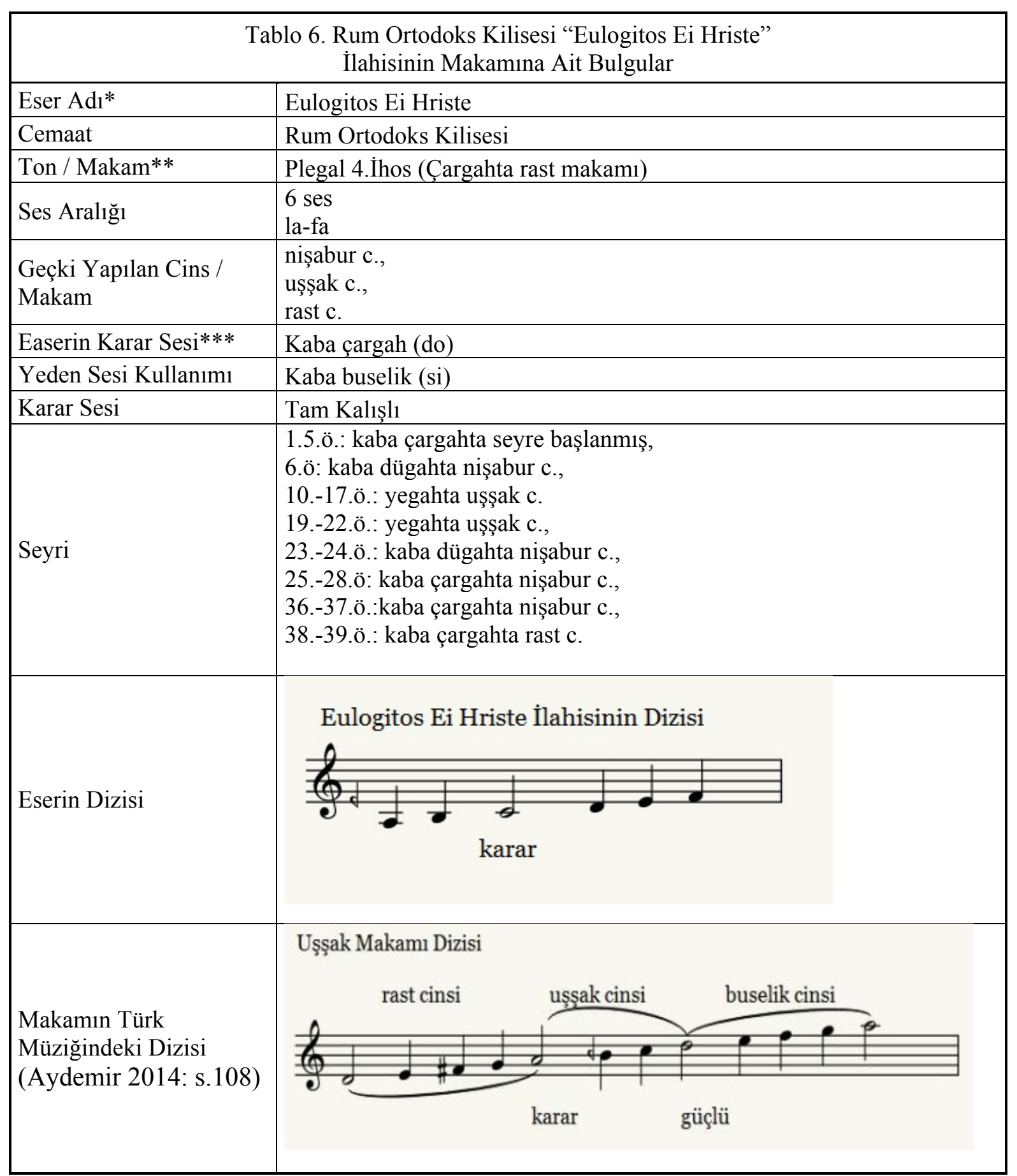

(Bakınız Ek 6)

\footnotetext{
*Eser, Aya Triada Kilisesi koro şefi Panteleimon Zafeiris’ten derlenmiştir.

** Eserin ton/makam bilgisini Panteleimon Zafeiris vermiştir.

***Eserin karar sesi bilgisi Panteleimon Zafeiris’ten alınmıştır.
} 
Tablo 7. Süryani Ortodoks Kilisesi "Malakho Men Şelyo"

İlahisinin Makamına Ait Bulgular

\begin{tabular}{|c|c|}
\hline Eser Ad1* & Malakho Men Şelyo \\
\hline Cemaat & Süryani Ortodoks Kilisesi \\
\hline Ton / Makam** & $\begin{array}{l}\text { Rbilcoyo } \\
\text { (yegahta rast makamı) }\end{array}$ \\
\hline Ses Aralığ 1 & $\begin{array}{l}8 \text { ses } \\
\text { si-si }\end{array}$ \\
\hline $\begin{array}{l}\text { Geçki Yapılan Cins / } \\
\text { Makam }\end{array}$ & $\begin{array}{l}\text { rast c., } \\
\text { uşşak c., } \\
\text { nişabur c. }\end{array}$ \\
\hline Easerin Karar Sesi & $\operatorname{Re}$ (yegah) \\
\hline Yeden Sesi Kullanımı & Yok \\
\hline Karar Sesi & Tam Kalışlı \\
\hline Seyri & $\begin{array}{l}\text { 1.-8.ö.: yegahta rast c., } \\
\text { 9.-12 ö.: yegahta rast c., } \\
\text { 13.ö.: hüseyni aşiranda uşşak c., } \\
\text { 14.-15.ö.: yegahta rast c., } \\
\text { 16.ö.: hüseyni aşiranda uşşak c., } \\
\text { 17.ö.: yegahta rast c., } \\
\text { 18.-19.ö.: kaba buselikte nişabur c., } \\
\text { 20.-21.ö.: yegahta rast c. }\end{array}$ \\
\hline Eserin Dizisi & Malakho Men Şelyo İlahisinin Dizisi \\
\hline $\begin{array}{l}\text { Makamın Türk } \\
\text { Müziğindeki Dizisi } \\
\text { (Aydemir 2014: s.33) }\end{array}$ & Rast Makamı Dizisi \\
\hline
\end{tabular}

(Bakınız Ek 7)

*Eser, Meryem Ana Süryani Kadim Kilisesi kızlar korosunda görev alan Yelda Akyüz'den derlenmiştir.

** Eserin ton/makam bilgisini Yelda Akyüz vermiştir. 


\begin{tabular}{|l|l|}
\hline \multicolumn{2}{|c|}{ Tablo 8. Süryani Ortodoks Kilisesi “Mşi'ho E'thi'led" } \\
İlahisinin Makamına Ait Bulgular
\end{tabular}

(Bakınız Ek 8)

\footnotetext{
*Eser, Meryem Ana Süryani Kadim Kilisesi kızlar korosunda görev alan Yelda Akyüz'den derlenmiştir.
}

** Eserin ton/makam bilgisini Yelda Akyüz vermiştir. 


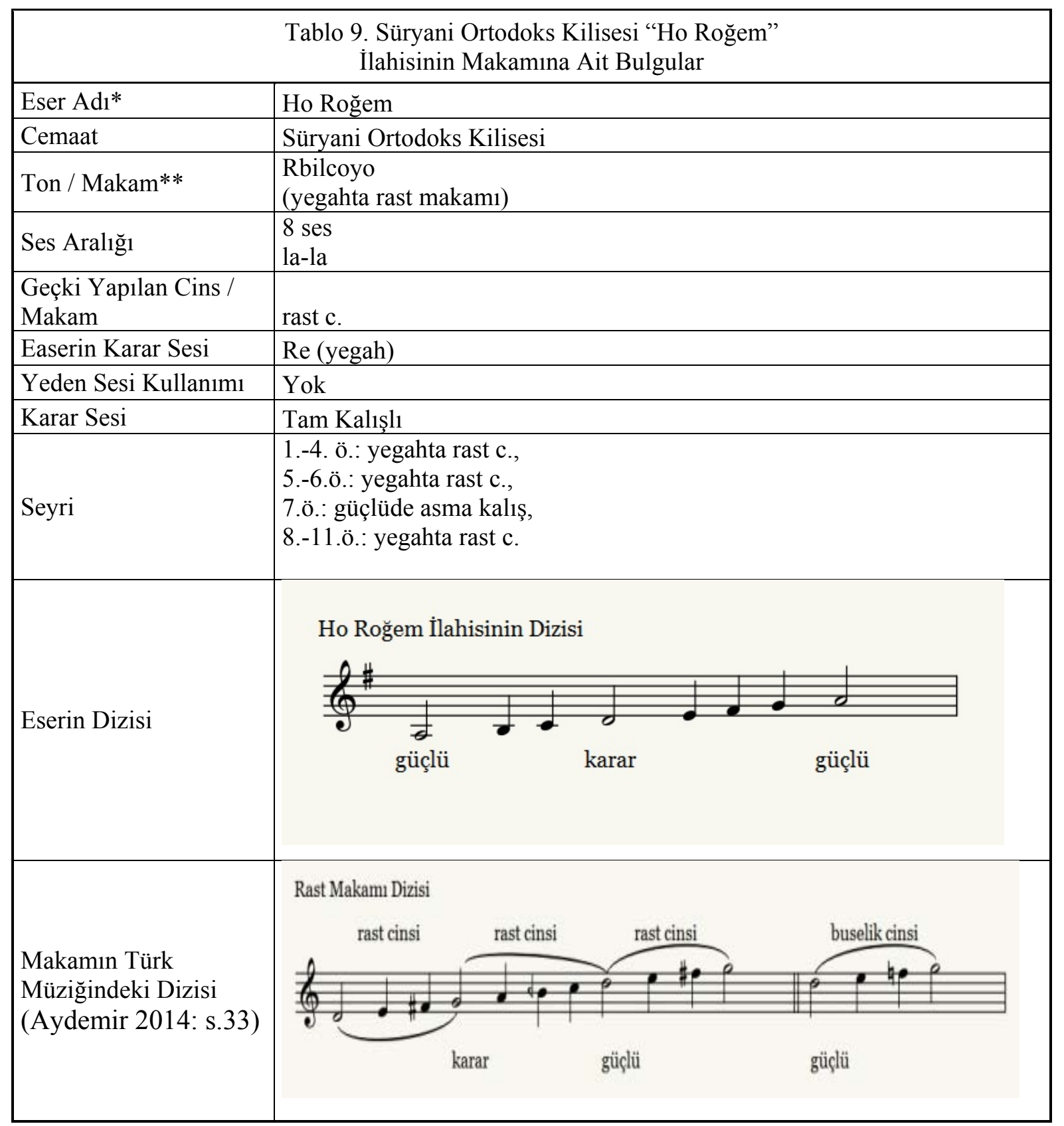

(Bakınız Ek 9)

*Eser, Meryem Ana Süryani Kadim Kilisesi kızlar korosunda görev alan Yelda Akyüz’den derlenmiştir.

** Eserin ton/makam bilgisini Yelda Akyüz vermiştir. 
Tablo 10. Süryani Ortodoks Kilisesi "Yavno Tlitho Thino Le" İlahisinin Makamına Ait Bulgular

\begin{tabular}{|c|c|}
\hline Eser $A d 1^{*}$ & Yavno Tlitho Thino Le \\
\hline Cemaat & Süryani Ortodoks Kilisesi \\
\hline Ton / Makam** & $\begin{array}{l}\text { Kadmoyo } \\
\text { (çargahta uşşak makamı) }\end{array}$ \\
\hline Ses Aralığ 1 & $\begin{array}{l}7 \text { ses } \\
\text { la-sol }\end{array}$ \\
\hline $\begin{array}{l}\text { Geçki Yapılan Cins / } \\
\text { Makam }\end{array}$ & $\begin{array}{l}\text { uşşak c., } \\
\text { çargah c. }\end{array}$ \\
\hline Easerin Karar Sesi & Do (kaba çargah) \\
\hline Yeden Sesi Kullanımı & Yok \\
\hline Karar Sesi & Tam Kalışlı \\
\hline Seyri & $\begin{array}{l}\text { 1.7.ö.: kaba çargahta uşşak c., } \\
\text { 8.-9.ö.: hüseyni aşiranda çargah c., } \\
\text { 11.-15.ö.: kaba çargahta uşşak c. }\end{array}$ \\
\hline Eserin Dizisi & $\begin{array}{l}\text { Yavno Tlitho Thino Le İlahisinin Dizisi } \\
\text { karar }\end{array}$ \\
\hline $\begin{array}{l}\text { Makamin Türk } \\
\text { Müziğindeki Dizisi } \\
\text { (Aydemir 2014: } \\
\text { s.108) }\end{array}$ & Ușşak Makamı Dizisi \\
\hline
\end{tabular}

(Bakınız Ek 10)

*Eser, Meryem Ana Süryani Kadim Kilisesi kızlar korosunda görev alan Yelda Akyüz’den derlenmiştir.

** Eserin ton/makam bilgisini Yelda Akyüz vermiştir. 
Tablo 11. Süryani Ortodoks Kilisesi "Hdav Ğame Hdav Ğame" İlahisinin Makamına Ait Bulgular

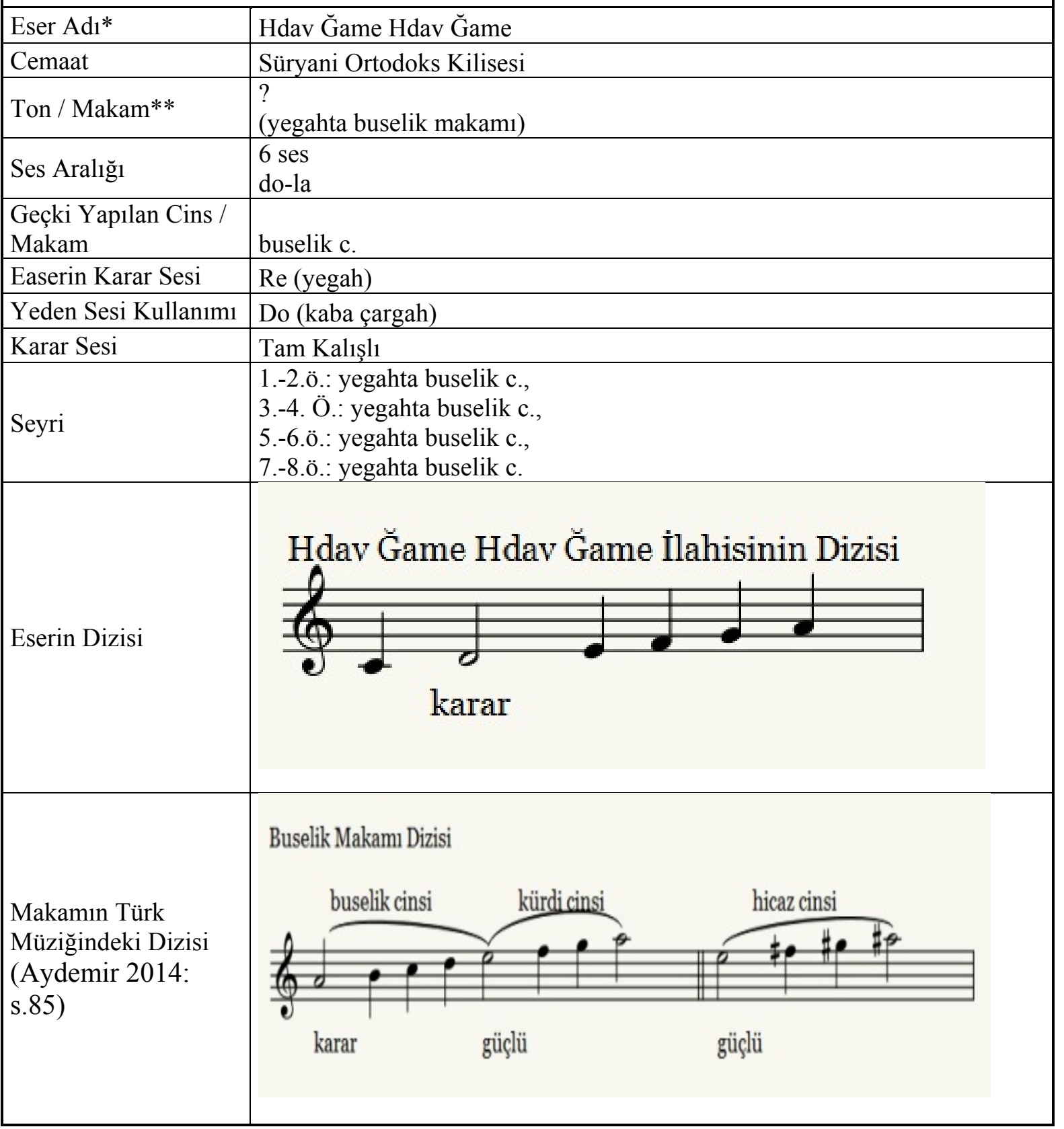

(Bakınız Ek 11)

*Eser, Meryem Ana Süryani Kadim Kilisesi kızlar korosunda görev alan Yelda Akyüz'den derlenmiştir.

** Makamın Süryani kültüründeki karşılığına ulaşılamamıştır. 


\section{Makamsal Özelliklere Ait Bulguların Karşılaştırılması}

\begin{tabular}{|c|c|}
\hline \multicolumn{2}{|c|}{$\begin{array}{c}\text { Tablo 12. Süryani Ortodoks ve Rum Ortodoks Kilisesi İlahilerinin } \\
\text { Ton / Makam Analizi }\end{array}$} \\
\hline Eser Ad1 & Ton / Makam \\
\hline Malakho Men Şelyo & Rast makamı \\
\hline Mşi'ho E'thi'led & Hüseyni makamı \\
\hline Ho Roğem & Rast makamı \\
\hline Yavnsak makamı Tlitho Thino Le & Buselik makamı \\
\hline Hdav Ğame Hdav Ğame & Hüzzam makamı \\
\hline O Monogenis Yios & Segah makamı \\
\hline I Genesis Sou & Uşşak makamı \\
\hline Xristos Genatai (a) & Uşşak makamı \\
\hline Xristos Genatai (b) & Hüseyni makamı \\
\hline Hristos Anesti & Rast makamı \\
\hline Eulogitos Ei Hriste &
\end{tabular}

\begin{tabular}{|l|c|}
\hline \multicolumn{2}{|c|}{ Tablo 13. Süryani Ortodoks Kilisesi İlahilerinin Ton / Makam Analizi } \\
\hline Ton / Makam & Adet \\
\hline Buselik makamı & 1 \\
\hline Hüseyni makamı & 2 \\
\hline Hüzzam makamı & 1 \\
\hline Rast makamı & 3 \\
\hline Segah makamı & 1 \\
\hline Uşşak makamı & 3 \\
\hline
\end{tabular}

Grafik 1. Süryani Ortodoks ve Rum Ortodoks Kilisesi İlahilerinin Ton / Makam Analizi

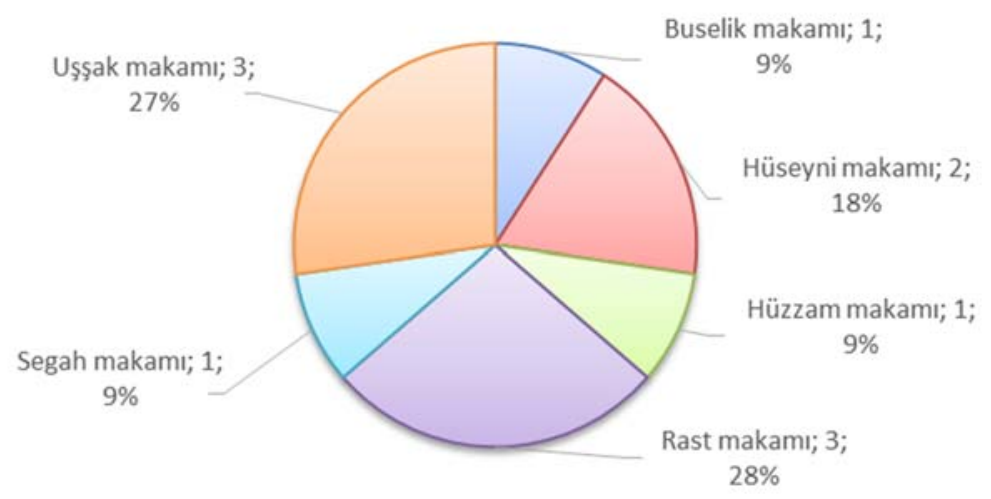

Karşılaştırma grafiği bize Süryani Ortodoks ve Rum Ortodoks Kiliselerinde rast ve uş̧ak makamlarının ortak kullanılan makamlar olduğunu göstermektedir. 
Tablo 14. Süryani Ortodoks ve Rum Ortodoks Kilisesi İlahilerinin Ses Aralığı Analizi

\begin{tabular}{|c|c|}
\hline Eser Adı & Ses Aralı̆̆ 1 \\
\hline Malakho Men Şelyo & 8 ses si-si \\
\hline Mşi'ho E’thi'led & 8 ses la-la \\
\hline Ho Roğem & 8 ses la-la \\
\hline Yavno Tlitho Thino Le & 7 ses la-sol \\
\hline Hdav Ğame Hdav Ğame & 6 ses do-la \\
\hline O Monogenis Yios & 6 ses la - fa diyez \\
\hline I Genesis Sou & 7 ses la diyez- sol \\
\hline Xristos Genatai (a) & 6 ses la-fa \\
\hline Xristos Genatai (b) & 10 ses sol-si bemol \\
\hline Hristos Anesti & 7 ses la-sol \\
\hline Eulogitos Ei Hriste & 6 ses la-fa \\
\hline
\end{tabular}

Tablo 15. Süryani Ortodoks ve Rum Ortodoks Kilisesi İlahilerinin Ses Aralığg Analizi

\begin{tabular}{|l|c|}
\hline Ses Aralığ1 & Adet \\
\hline 6 ses & 4 \\
\hline 7 ses & 3 \\
\hline 8 ses & 3 \\
\hline 10 ses & 1 \\
\hline
\end{tabular}

Grafik 2. Süryani Ortodoks ve Rum Ortodoks Kilisesi İlahilerinin Ses Aralığı Analizi

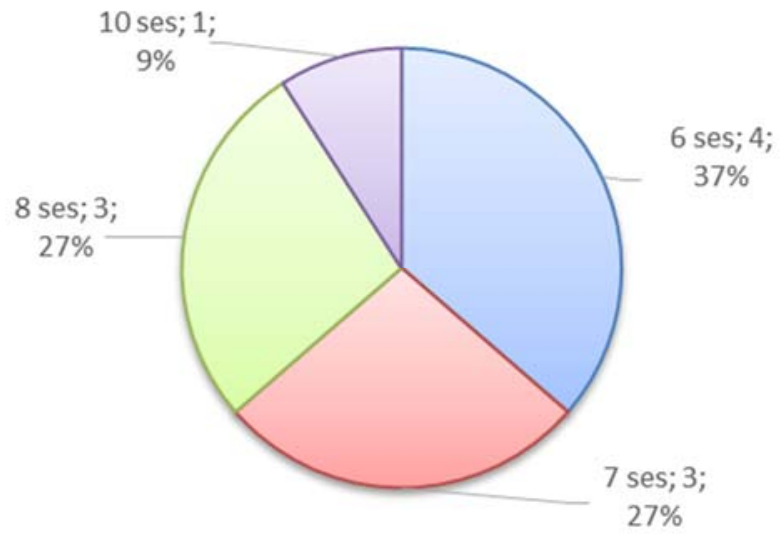

Karşılaştırma grafiği bize Süryani ve Rum Ortodoks Kilisesi doğuş ilahilerinde kullanılan ses aralığının bir oktavı aşmadığını göstermektedir. En yoğun olarak ilahilerin altı ses içinde gezindiği sonucuna varmaktayız. Rum Ortodoks Kilisesi ilahisi olan "Xristos Genatai"nin iki versiyonu arasındaki ses farkı da dikkat çekicidir. 


\begin{tabular}{|c|c|}
\hline \multicolumn{2}{|c|}{$\begin{array}{c}\text { Tablo 16. Süryani Ortodoks ve Rum Ortodoks Kilisesi İlahilerinde } \\
\text { Geçki Yap1lan Cins/Makam Analizi }\end{array}$} \\
\hline Eser Ad1 & Geçki Yapılan Cins/Makam \\
\hline Malakho Men Şelyo & rast c., uşşak c., nişabur c. \\
\hline Mşi'ho E'thi'led & hüseyni c., uşşak c. \\
\hline Ho Roğem & rast c. \\
\hline Yavno Tlitho Thino Le & uşşak c., çargah c. \\
\hline Hdav Ğame Hdav Ğame & buselik c. \\
\hline O Monogenis Yios & segah c., uşşak c., hicaz c. \\
\hline I Genesis Sou & hicaz c., uşşak c., segah c. \\
\hline Xristos Genatai (a) & uşşak c., buselik c., segah c. \\
\hline Xristos Genatai (b) & uşşak c., rast c., segah c., buselik c. \\
\hline Hristos Anesti & hüseyni c., buselik c., rast c., çargah c., uşşak c. \\
\hline Eulogitos Ei Hriste & nişabur c., uşşak c., rast c. \\
\hline
\end{tabular}

\begin{tabular}{|l|c|}
\hline \multicolumn{2}{|c|}{$\begin{array}{c}\text { Tablo 17. Süryani Ortodoks ve Rum Ortodoks Kilisesi İlahilerinde } \\
\text { Geçki Yapılan Cins/Makam Analizi }\end{array}$} \\
\hline \multicolumn{1}{|c|}{ Geçki Yapılan Cins/Makam } & Adet \\
\hline Buselik Cinsi & 4 \\
\hline Çargah Cinsi & 2 \\
\hline Hicaz Cinsi & 2 \\
\hline Hüseyni Cinsi & 2 \\
\hline Nişabur Cinsi & 2 \\
\hline Rast Cinsi & 5 \\
\hline Segah Cinsi & 4 \\
\hline Uşşak Cinsi & 9 \\
\hline
\end{tabular}

Grafik 3. Süryani Ortodoks ve Rum Ortodoks Kilisesi İlahilerinde Geçki Yapılan Cins/Makam Analizi

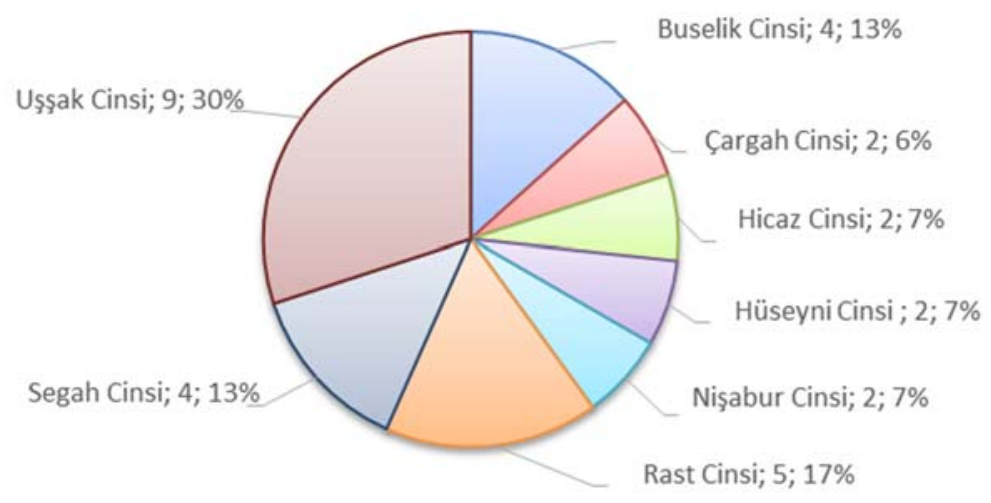

Karşılaştırma grafiği bize Süryani Ortodoks ve Rum Ortodoks Kiliselerinin mevlid ilahilerinde en çok geçki yapılan cinsin uşşak cinsi olduğunu göstermektedir. Daha sonra en çok kullanıldı̆̆ edilmiştir. Her iki kilisenin de ilahilerinde nişabur cinsinin kullanıldığı gözlenmiştir. 


\begin{tabular}{|l|l|}
\hline \multicolumn{2}{|c|}{ Tablo 18. Süryani Ortodoks ve Rum Ortodoks Kilisesi İlahilerinin Karar Sesi Analizi } \\
\hline Eser Adı & Eserin Karar Sesi \\
\hline Malakho Men Şelyo & re (yegah) \\
\hline Mşi'ho E'thi'led & fa diyez (evç) \\
\hline Ho Roğem & re (yegah) \\
\hline Yavno Tlitho Thino Le & do (kaba çargah) \\
\hline Hdav Ğame Hdav Ğame & re (yegah) \\
\hline O Monogenis Yios & re (yegah) \\
\hline I Genesis Sou & si (segah) \\
\hline Xristos Genatai (a) & la (kaba dügah) \\
\hline Xristos Genatai (b) & si (kaba buselik) \\
\hline Hristos Anesti & re (neva) \\
\hline Eulogitos Ei Hriste & do (kaba çargah) \\
\hline
\end{tabular}

\begin{tabular}{|l|c|}
\hline \multicolumn{2}{|c|}{ Tablo 19. Süryani Ortodoks ve Rum Ortodoks Kilisesi İlahilerinin Karar Sesi Analizi } \\
\hline Eserin Karar Sesi & Adet \\
\hline do (kaba çargah) & 2 \\
\hline fa diyez (evç) & 1 \\
\hline la (kaba dügah) & 1 \\
\hline re (neva) & 1 \\
\hline re (yegah) & 4 \\
\hline si (kaba buselik) & 1 \\
\hline si (segah) & 1 \\
\hline
\end{tabular}

Grafik 4. Süryani Ortodoks ve Rum Ortodoks Kilisesi İlahilerinin Karar Sesi Analizi

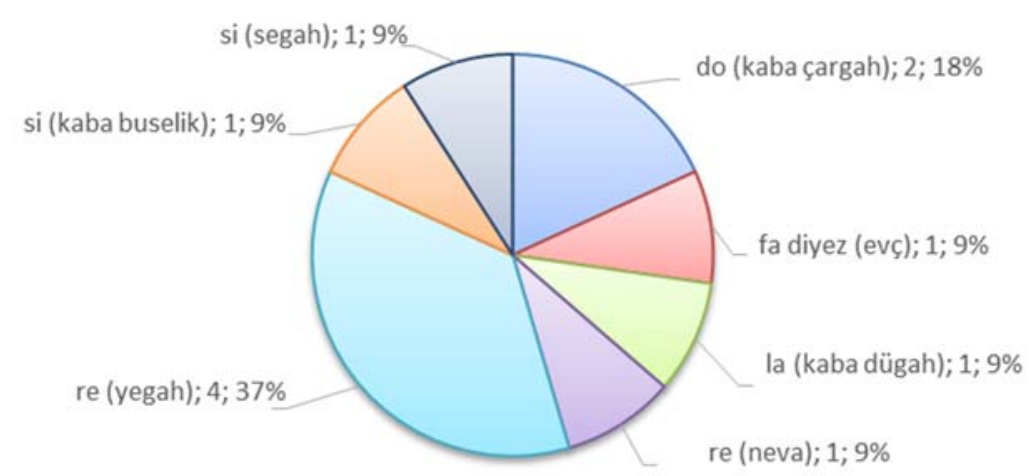

Karşılaştırma grafiğine bakarak Süryani Ortodoks ve Rum Ortodoks Kilisesi doğuş ilahilerinin genellikle re (yegah) sesinde karar verdiği tespit edilmiştir. 


\begin{tabular}{|c|c|}
\hline \multicolumn{2}{|c|}{ Tablo 20. Süryani Ortodoks ve Rum Ortodoks Kilisesi İlahilerinin } \\
Yeden Sesi Kullanımı Analizi
\end{tabular}

\begin{tabular}{|l|c|}
\hline \multicolumn{2}{|c|}{$\begin{array}{c}\text { Tablo 21. Süryani Ortodoks ve Rum Ortodoks Kilisesi İlahilerinin } \\
\text { Yeden Sesi Kullanımı Analizi }\end{array}$} \\
\hline \multicolumn{1}{|c|}{ Yeden Sesi Kullanımı } & Adet \\
\hline do (kaba çargah) & 2 \\
\hline do diyez (nim hicaz) & 1 \\
\hline si (kaba buselik) & 1 \\
\hline Yok & 7 \\
\hline
\end{tabular}

Grafik 5. Süryani Ortodoks ve Rum Ortodoks Kilisesi İlahilerinin Yeden Sesi Kullanımı Analizi

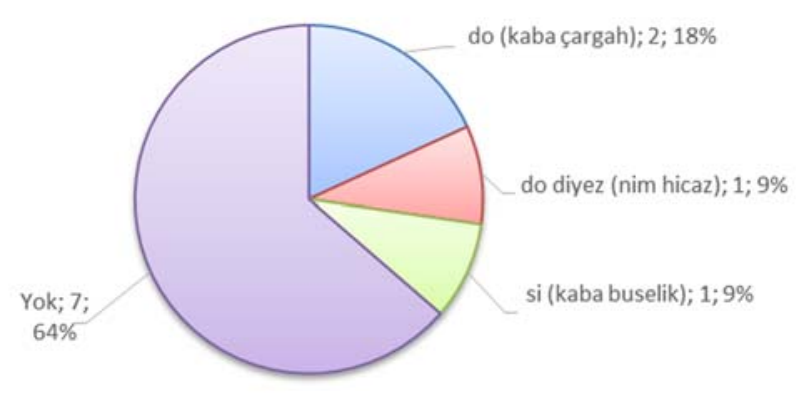

Karşılaştırma grafiğinden yola çıkarak Süryani Ortodoks ve Rum Ortodoks kilisesi doğuş ilahilerinde çoğunlukla yeden sesi kullanımı olmadığı tespit edilmiştir. 


\begin{tabular}{|c|c|}
\hline Eser Ad1 & Eserin Nihâyî Kararı \\
\hline Malakho Men Şelyo & Tam Kalışl1 \\
\hline Mşi'ho E'thi'led & Asma Kalışlı \\
\hline Ho Roğem & Tam Kalışlı \\
\hline Yavno Tlitho Thino Le & Tam Kalışlı \\
\hline Hdav Ğame Hdav Ğame & Tam Kalışl1 \\
\hline O Monogenis Yios & Asma Kalışli \\
\hline I Genesis Sou & Tam Kalışl1 \\
\hline Xristos Genatai (a) & Tam Kalışlı \\
\hline Xristos Genatai (b) & Tam Kalışl1 \\
\hline Hristos Anesti & Asma Kalışlı \\
\hline Eulogitos Ei Hriste & Tam Kalışl1 \\
\hline
\end{tabular}

\begin{tabular}{|l|c|}
\hline \multicolumn{2}{|c|}{ Tablo 23. Süryani Ortodoks ve Rum Ortodoks Kilisesi İlahilerinin Nihâyî Karar Sesi } \\
Analizi
\end{tabular}

Grafik 6. Süryani Ortodoks ve Rum Ortodoks Kilisesi İlahilerinin Nihâyî Karar Sesi Analizi

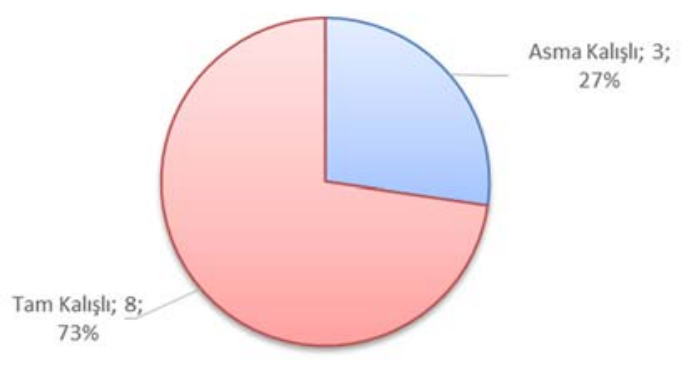

Karş1laştırma grafiği Süryani Ortodoks ve Rum Ortodoks doğuş ilahilerinde karar seslerinin genellikle tam kalışla bittiğini, az da olsa bu iki dinin müzik geleneğinde kararın asma kalışlı da olabileceğini ortaya koymaktadır. 


\begin{tabular}{|c|c|}
\hline \multicolumn{2}{|c|}{ Tablo 24. Süryani Ortodoks ve Rum Ortodoks Kilisesi İlahilerinin Seyri Analiz } \\
\hline Eser Adi & Seyri \\
\hline Malakho Men Şelyo & $\begin{array}{c}\text { 1.-8.ö.: yegahta rast c., } \\
\text { 9.-12 ö.: yegahta rast c., } \\
\text { 13.ö.: hüseyni aşiranda uşşak c., } \\
\text { 14.-15.ö.: yegahta rast c., } \\
\text { 16.ö.: hüseyni aşiranda uşşak c., } \\
\text { 17.ö.: yegahta rast c., } \\
\text { 18.-19.ö.: kaba buselikte nişabur c., } \\
\text { 20.-21.ö.: yegahta rast c. } \\
\end{array}$ \\
\hline Mşi'ho E'thi'led & $\begin{array}{l}\text { 1.-7.ö.: kaba buselikte hüseyni c., } \\
\text { 8.-21.ö.: kaba buselikte hüseyni c. } \\
\text { 22.-25.ö.: kaba buselikte uşşak c., } \\
\text { 26.-30.ö.: güçlü seste karara gidilmiş }\end{array}$ \\
\hline Ho Roğem & $\begin{array}{l}\text { 1.-4. ö.: yegahta rast c., } \\
\text { 5.-6.ö.: yegahta rast c., } \\
\text { 7.ö.: güçlüde asma kalış, } \\
\text { 8.-11.ö.: yegahta rast c. }\end{array}$ \\
\hline Yavno Tlitho Thino Le & $\begin{array}{l}\text { 1.7.ö.: kaba çargahta uşşak c., } \\
\text { 8.-9.ö.: hüseyni aşiranda çargah c., } \\
\text { 11.-15.ö.: kaba çargahta uşşak c. }\end{array}$ \\
\hline Hdav Ğame Hdav Ğame & $\begin{array}{l}\text { 1.-2.ö.: yegahta buselik c., } \\
\text { 3.-4. ö.: yegahta buselik c., } \\
\text { 5.-6.ö.: yegahta buselik c., } \\
\text { 7.-8.ö.: yegahta buselik c. }\end{array}$ \\
\hline O Monogenis Yios & $\begin{array}{l}\text { 1.-13.ö.:kaba segahta segah c., } \\
\text { 17.-29.ö.: kaba dügahta uşşak c. } \\
\text { 30.-33.ö.:yegahta hicaz c. } \\
\text { 34.-38.ö.:kaba segahta segah c. } \\
\text { 39.-41.ö.: yegahta asma kalış }\end{array}$ \\
\hline I Genesis Sou & $\begin{array}{l}\text { 1.-2. ö. : güçlü ses ile seyre başlamış, } \\
\text { 3.-4.ö.: nevada hicaz c., } \\
\text { 5. ö. Segahta segah c., } \\
\text { 7.-8.ö.: nevada hicaz c., } \\
\text { 9.ö.: segahta segah c., } \\
\text { 10.-14. ö., nevada hicaz c., } \\
\text { 15.-16.ö.: segahta segah c., } \\
\text { 17.-18. ö. : dügahta uşşak c., } \\
\text { 19.-24.ö.: nevada hicaz c., } \\
\text { 25.ö.:segahta segah c. }\end{array}$ \\
\hline Xristos Genatai (a) & $\begin{array}{l}\text { 2.-5.ö.: dügahta uşşak c., } \\
\text { 6.-9.ö.: nevada buselik c., } \\
\text { 10.-11.ö.: sagahta segah c., } \\
\text { 13.ö.: nevada buselik c. } \\
\text { 14.ö.: segahta segah c., } \\
\text { 15.ö.: dügahta uşşak c. }\end{array}$ \\
\hline
\end{tabular}




\begin{tabular}{|c|c|}
\hline Xristos Genatai (b) & $\begin{array}{l}\text { 1.-9.ö.: kaba buselikte uşşak c., } \\
\text { 10.-14.ö.: hüseyni aşiranda rast c. } \\
\text { 15.-17.ö.: kaba buselikte uşşak c. } \\
\text { 18.-20.ö.: kaba rastta segah c. } \\
\text { 21.-23.ö.: hüseyni aşiranda buselik c. } \\
\text { 24.-27.ö.:kaba buselikte uşşak c. } \\
\text { 28.-38.ö.: kaba buselikte uşşak c. }\end{array}$ \\
\hline Hristos Anesti & $\begin{array}{c}\text { 1.-2.ö.: karar sesi gösterilmiş, } \\
\text { 3.-5.ö.: dügahta hüseyni c., } \\
\text { 6.-7.ö.: nevada buselik c., } \\
\text { 9.-13.ö.: nevada rast c., } \\
\text { 14.-17.ö.: çargahta çargah c., } \\
\text { 18.-19.ö.: nevada buselik c., } \\
\text { 20.-25.ö.: nevada buselik c., } \\
\text { 27.-28.ö.: dügahta uşşak c., } \\
\text { 29.-31.ö.: nevada buselik c., } \\
\text { 32-33.ö.: nevada kalış }\end{array}$ \\
\hline Eulogitos Ei Hriste & $\begin{array}{l}\text { 1.5.ö.: kaba çargahta seyre başlanmış, } \\
\text { 6.ö: kaba dügahta nişabur c., } \\
\text { 10.-17.ö.: yegahta uşşak c. } \\
\text { 19.-22.ö.: yegahta uşşak c., } \\
\text { 23.-24.ö.: kaba dügahta nişabur c., } \\
\text { 25.-28.ö: kaba çargahta nişabur c., } \\
\text { 36.-37.ö.:kaba çargahta nişabur c., } \\
\text { 38.-39.ö.: kaba çargahta rast c. } \\
\end{array}$ \\
\hline
\end{tabular}

Tablo 25. Süryani Ortodoks ve Rum Ortodoks Kilisesi İlahilerinin Seyri Analizi

\begin{tabular}{|l|c|}
\hline Seyir & Adet \\
\hline çargahta çargah c. & 1 \\
\hline dügahta hüseyni c. & 1 \\
\hline dügahta uşşak c. & 4 \\
\hline hüseyni aşiranda buselik c. & 1 \\
\hline hüseyni aşiranda çargah c. & 1 \\
\hline hüseyni aşiranda rast c. & 1 \\
\hline hüseyni aşiranda uşşak c. & 2 \\
\hline kaba buselikte hüseyni c. & 2 \\
\hline kaba buselikte nişabur c. & 1 \\
\hline kaba buselikte uşşak c. & 5 \\
\hline kaba çargahta nişabur c. & 2 \\
\hline kaba çargahta rast c. & 1 \\
\hline kaba çargahta uşşak c. & 2 \\
\hline kaba dügahta nişabur c. & 2 \\
\hline kaba dügahta uşşak c. & 1 \\
\hline kaba rastta segah c. & 1 \\
\hline kaba segahta segah c. & 2 \\
\hline
\end{tabular}




\begin{tabular}{|l|l|}
\hline nevada buselik c. & 6 \\
\hline nevada hicaz c. & 4 \\
\hline nevada rast c. & 1 \\
\hline sagahta segah c. & 6 \\
\hline yegahta buselik c. & 4 \\
\hline yegahta hicaz c. & 1 \\
\hline yegahta rast c. & 8 \\
\hline yegahta uşşak c. & 2 \\
\hline çargahta çargah c. & 1 \\
\hline dügahta hüseyni c. & 1 \\
\hline dügahta uşşak c. & 4 \\
\hline hüseyni aşiranda buselik c. & 1 \\
\hline hüseyni aşiranda çargah c. & 1 \\
\hline hüseyni aşiranda rast c. & 1 \\
\hline
\end{tabular}

Grafik 7. Süryani Ortodoks ve Rum Ortodoks Kilisesi İlahilerinin Seyri Analizi

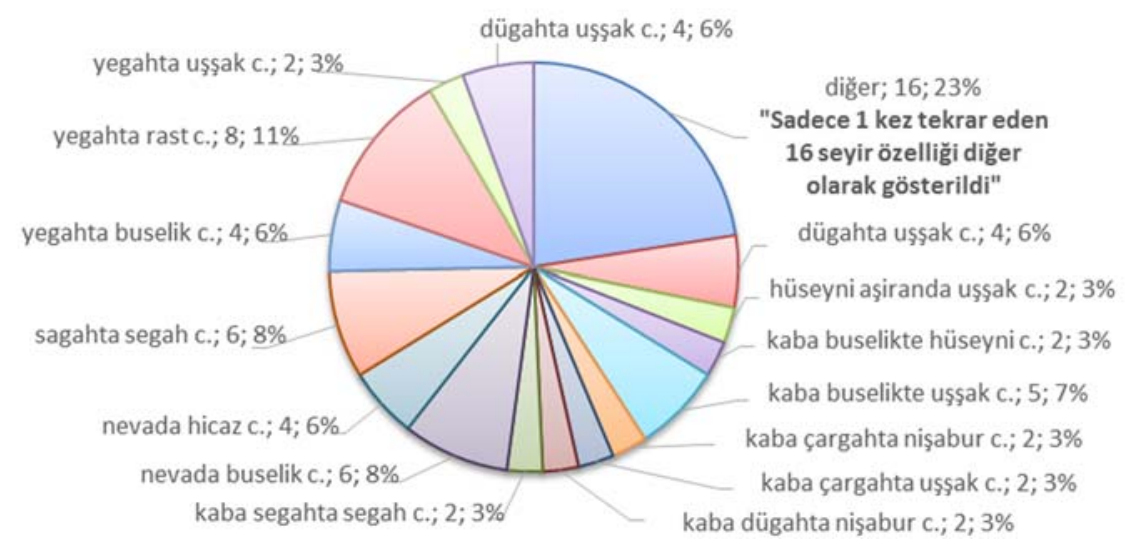

Karşılaştırma grafiği Süryani Ortodoks ve Rum Ortodoks Kiliseleri doğuş ilahilerine bakıldığı zaman en çok yegahta rast, segahta segah ve nevada buselik cinsinin kullanıldığ

\section{Sonuç}

Süryani Ortodoks ve Rum Ortodoks Kiliselerinde rast ve uşşak makamlarının ortak kullanılan makamlar olduğu, kullanılan ses aralığının bir oktavı aşmadığ 1 tespit edilmiştir. En yoğun olarak ilahilerin altı ses içinde gezindiği, ilahilerin genellikle re (yegah) sesinde karar verdiği ortaya çıkmıştır. Bu iki mezhebin doğuş ilahilerinde çoğunlukla yeden sesi kullanımı olmadığı, karar seslerinin genellikle tam kalışlı bittiği, az da olsa bu iki dinin müzik geleneğinde kararın asma kalışlı da olabileceği gözlemlenmiştir. İlahilerin seyrinde en çok yegahta rast, segahta segah ve nevada buselik cinsinin kullanıldığı tespit edilmiştir. Böylece Hipotezin geçerli olduğu, Süryani Ortodoks ve Rum Ortodoks ilahilerinde makamsal özelliklerinin benzediği ortaya çıkmıştır. 


\section{REFERENCES}

- YEPREM, Safa (2004), "Türk Cami Musikisi İle Mukayeseli Olarak İstanbul Gayr-i Müslimlerinde Mabet Musikisi”, Marmara Üniversitesi Sosyal Bilimler Enstitüsü, Yayınlanmamış Doktora Tezi

- ÖZKAN, İsmail Hakkı (2014) “Türk Musikisi Nazariyatı ve Usulleri Kudüm Velveleleri”, Ötüken Neşriyat, İstanbul

- AYDEMIR, Murat (2014) "Türk Müziği Makam Rehberi”, Pan Yayıncılık, İstanbul

- ARSLAN, Ayşegül (2015) "Semavi Dinlerin İstanbul'daki Mabetlerinde İcra Edilen Doğuş İlahilerinin Karşılaştırmalı Analizi” Marmara Üniversitesi Sosyal Bilimler Enstitüsü, Yayınlanmamış Yüksek Lisans Tezi 


\section{EKLER}

Ek 1

\section{O Monogenis Yios}
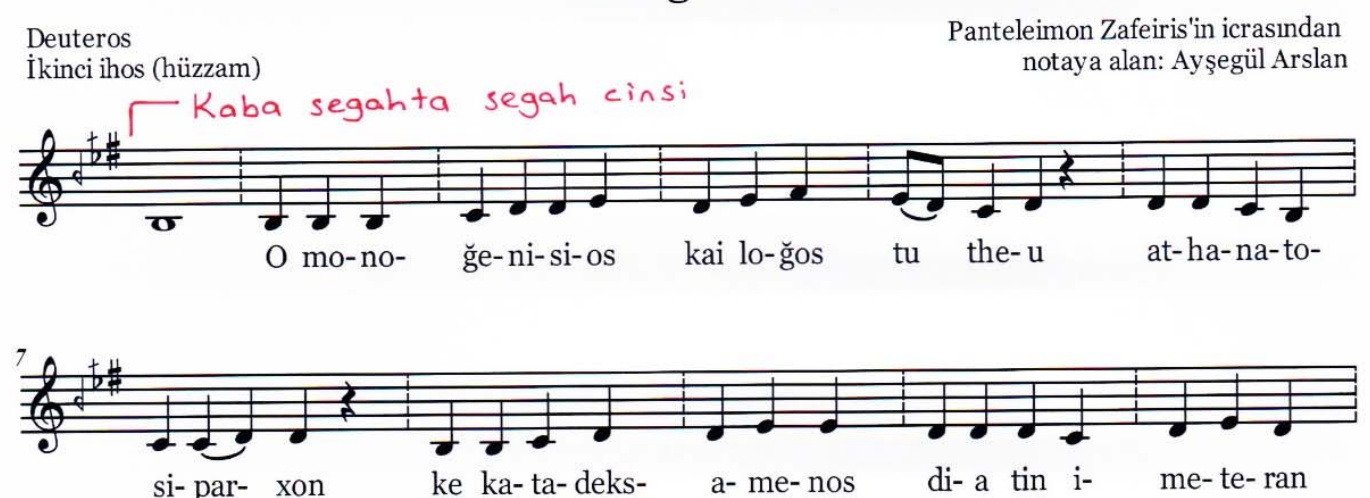

si- par- xon

ke ka- ta- deks-

a- me-nos

- kaba dügahta us șak c.

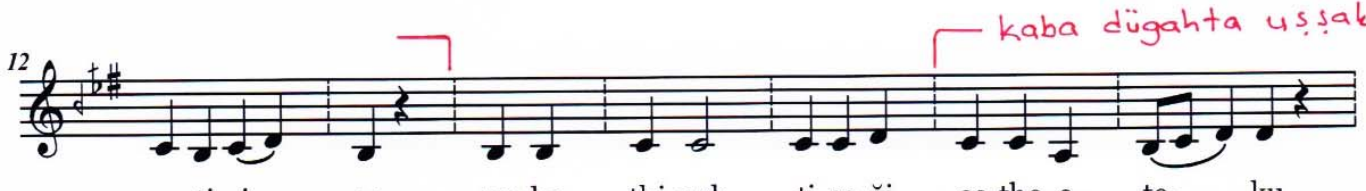

so-ti-ri

an

sar-ko-

thi-nek

ti-sa-ği-

as the-o-

to- $\mathrm{ku}$

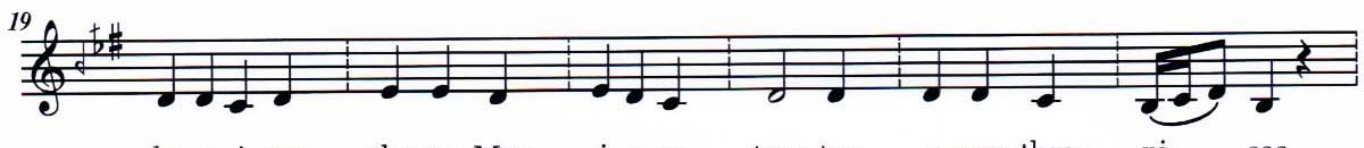

ke a- i- par- the-nu Mar- i- a-sa trep-tos e-nan-thro- pi- sas
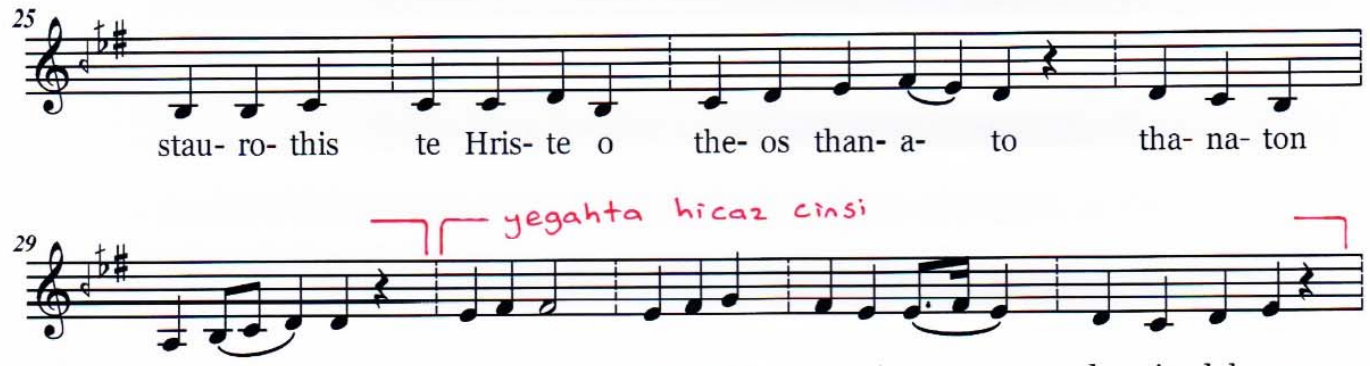
pa- ti-
$\mathrm{i}$ - is on
tis a- ği-
as tri- a
dos sin-dok-sa-

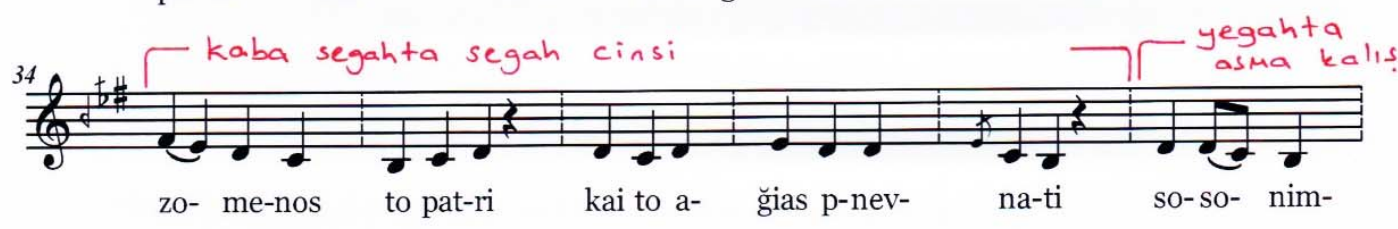




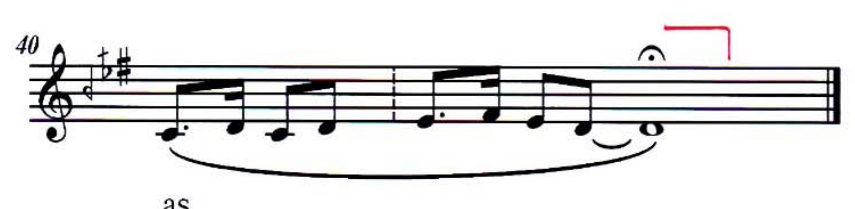

as 
Ek 2
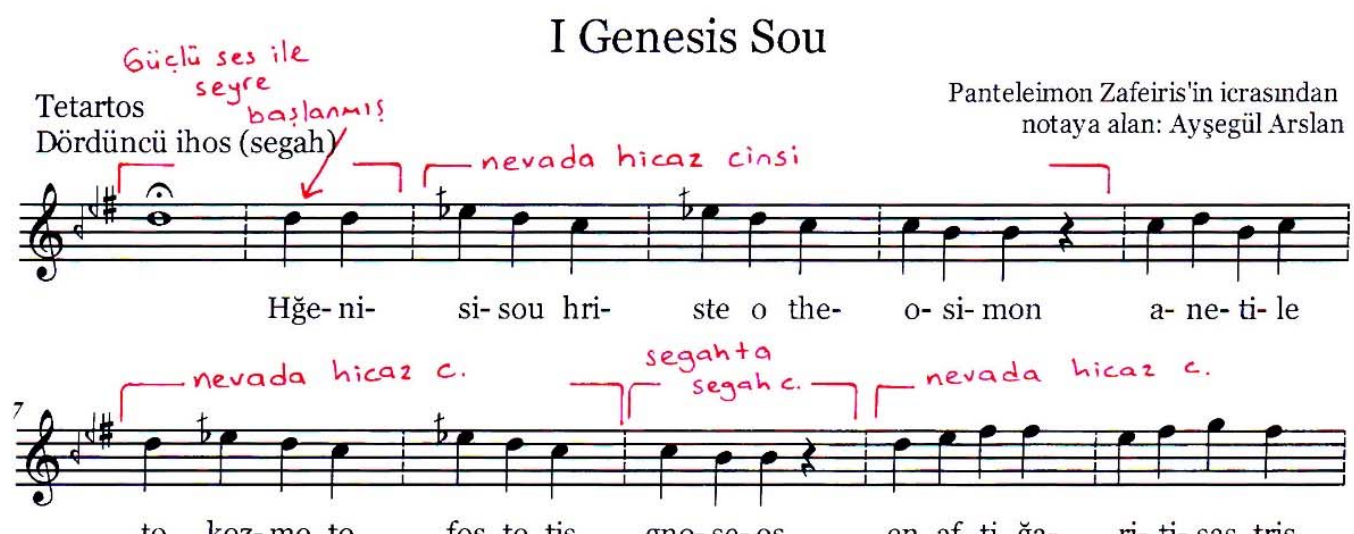
to koz-mo to
fos to tis
gno-se-os
en af- ti ğa-
ri- ti- sas-tris
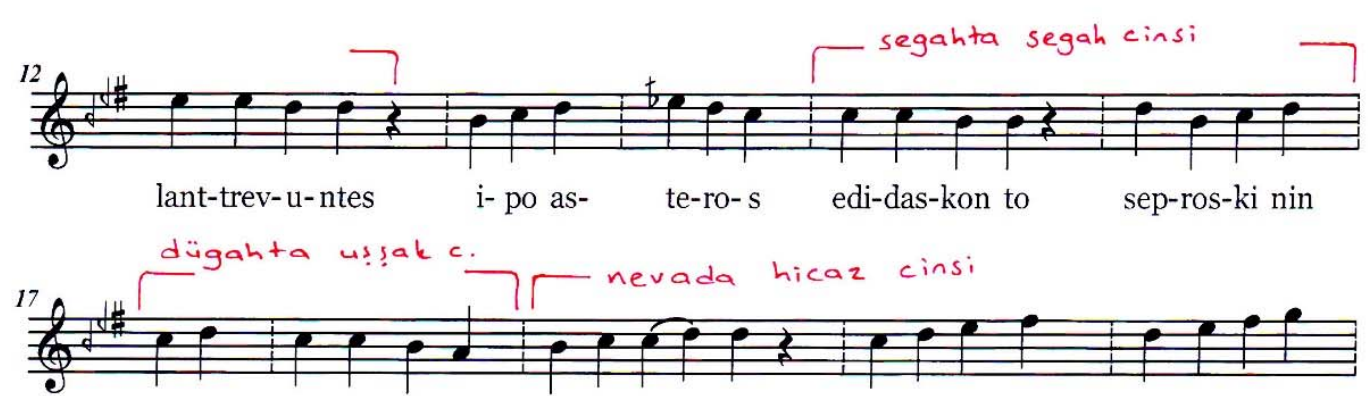

to-ni- li- yon tis di- ke-os-si- nis ke se ği-ğnos- kin ek-si-ip-

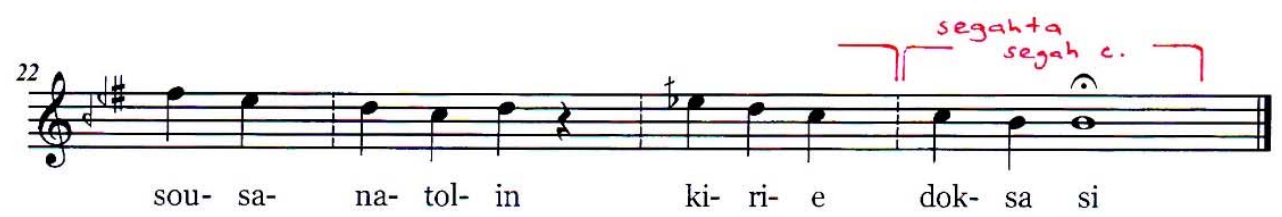


Ek 3

\section{Xristos Genatai (a)}

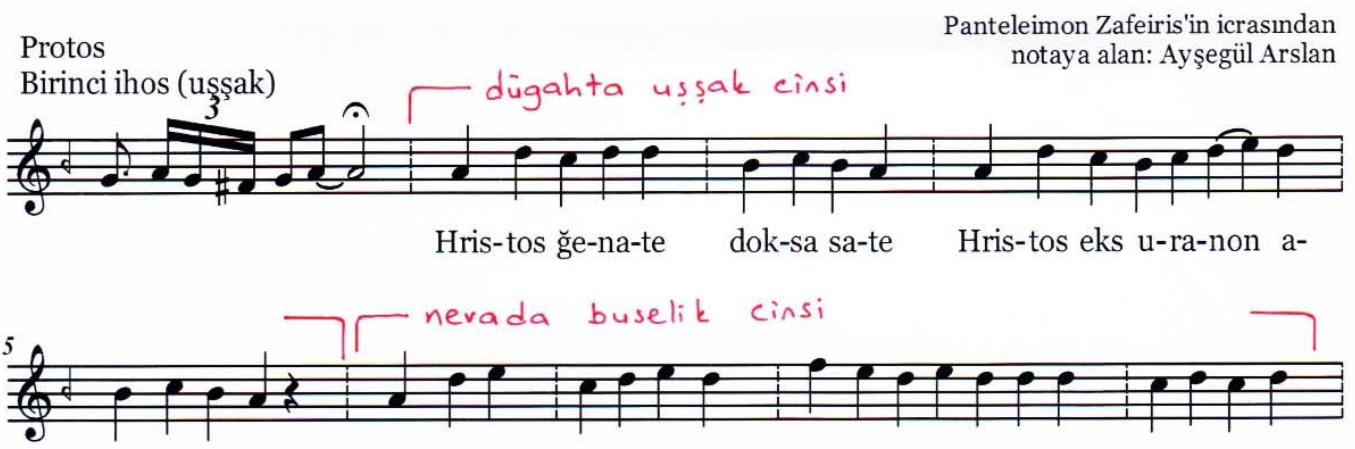

pan-di-sa-te Hris-to-s e-pi ği-sip- sot-hi-te a-sa-te to ki-ri- o pa-
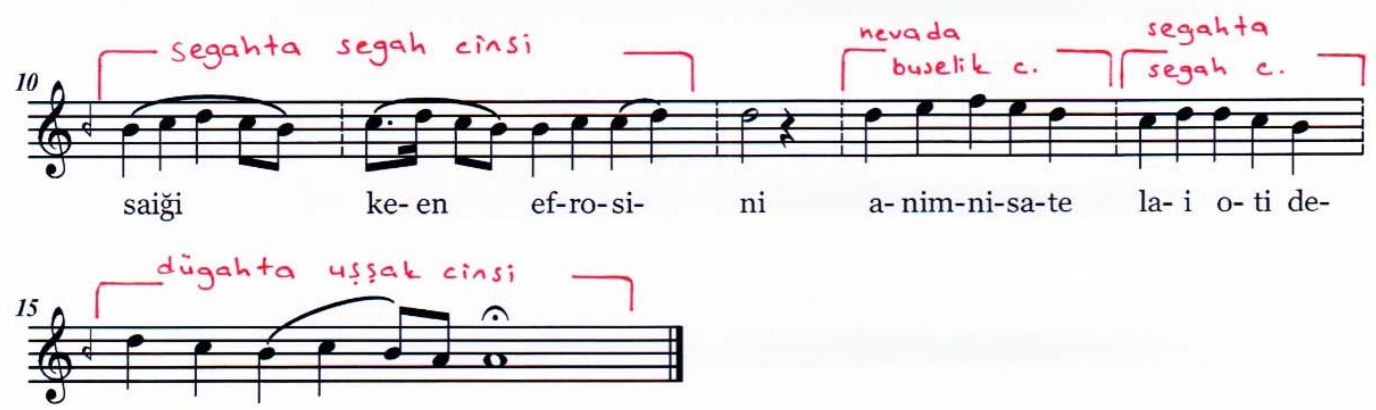

do- ks- sa- 
Ek 4
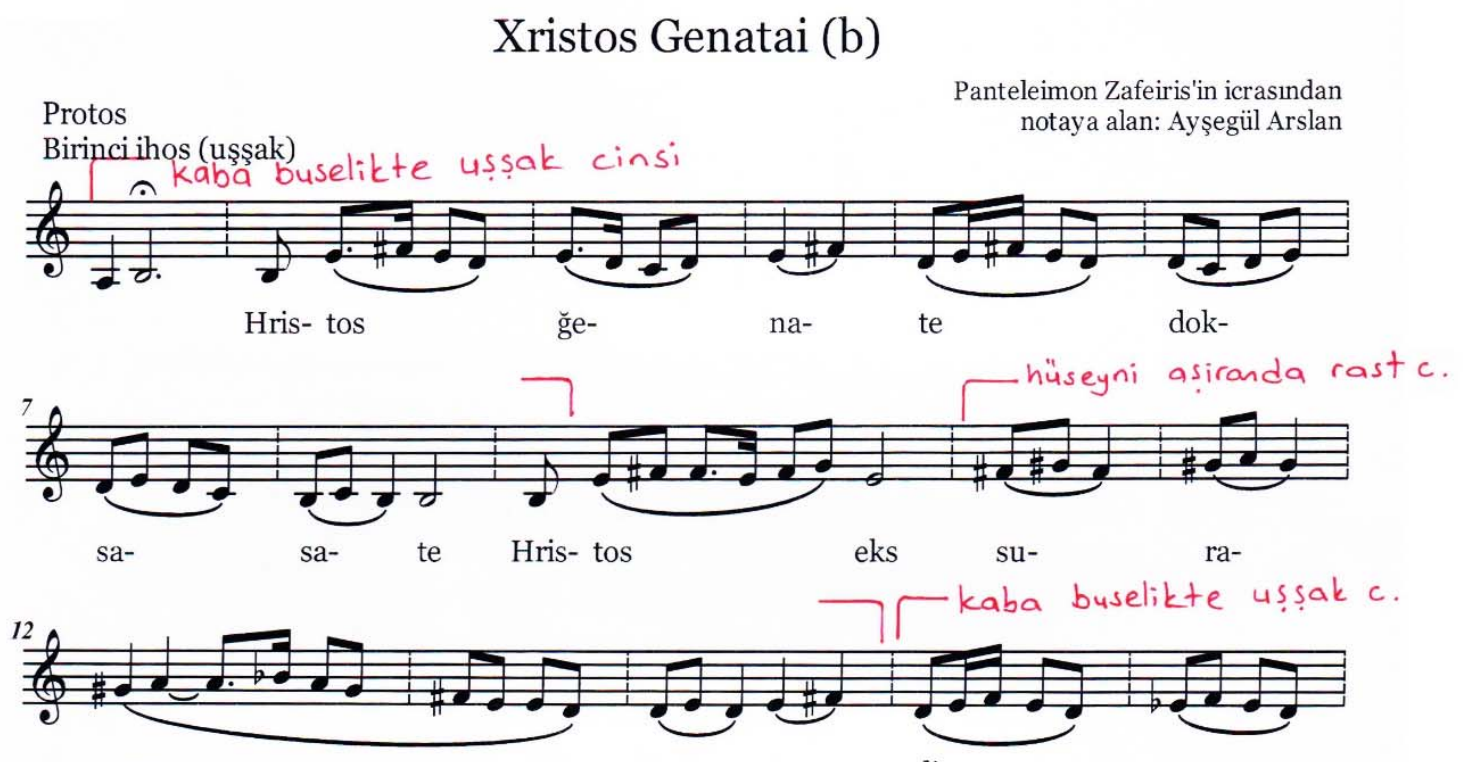

non

a- pan-

dis-

sa-

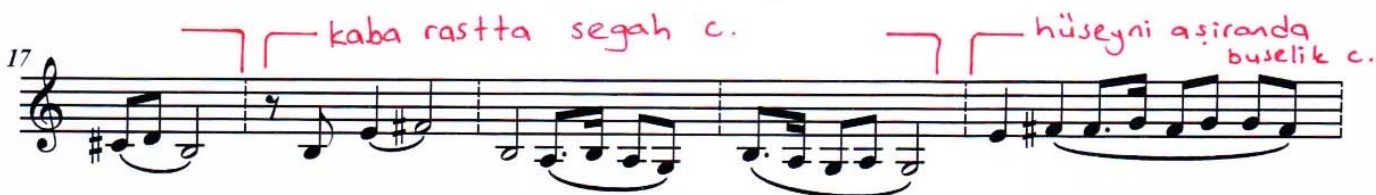

te Hris-tos

e- pi

gis

ip- sot-

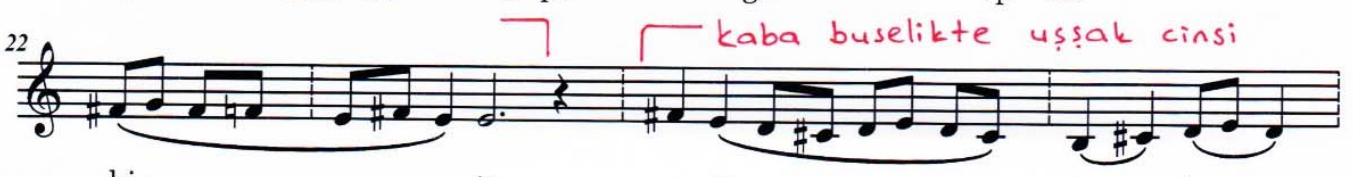

hi-

te

a- sa-

te

to

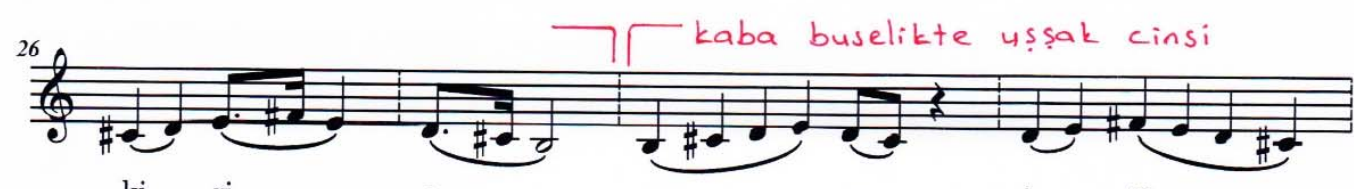

ki- ri-

o

pa-

sa-

ği

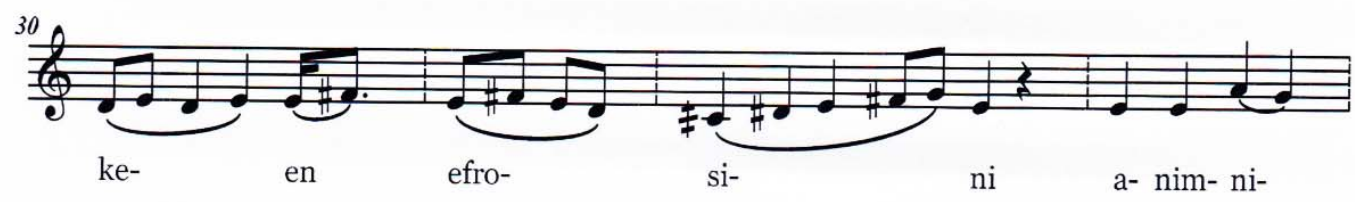




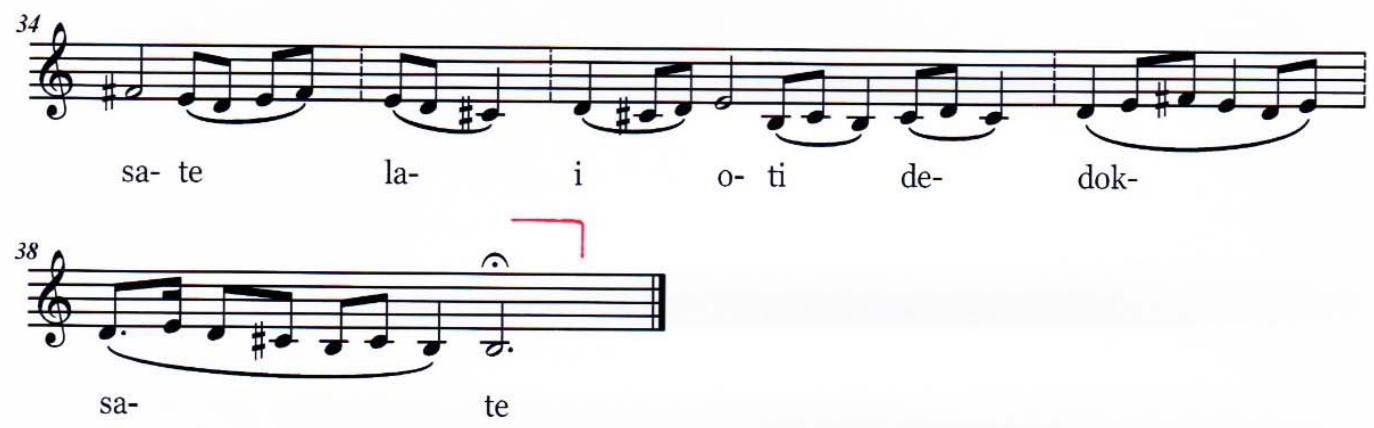


Ek 5
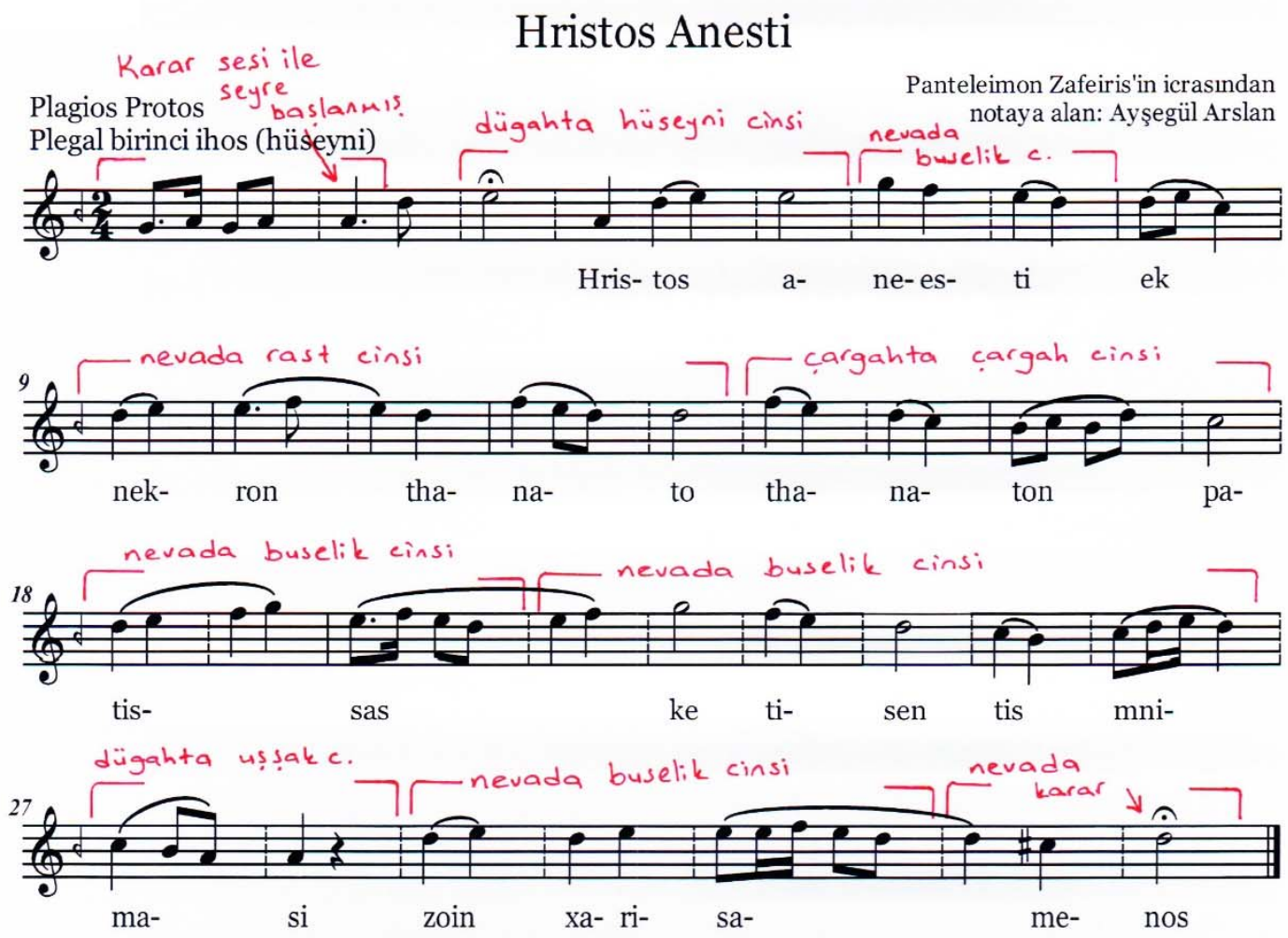
Ek 6

\section{Eulogitos ei Hriste}
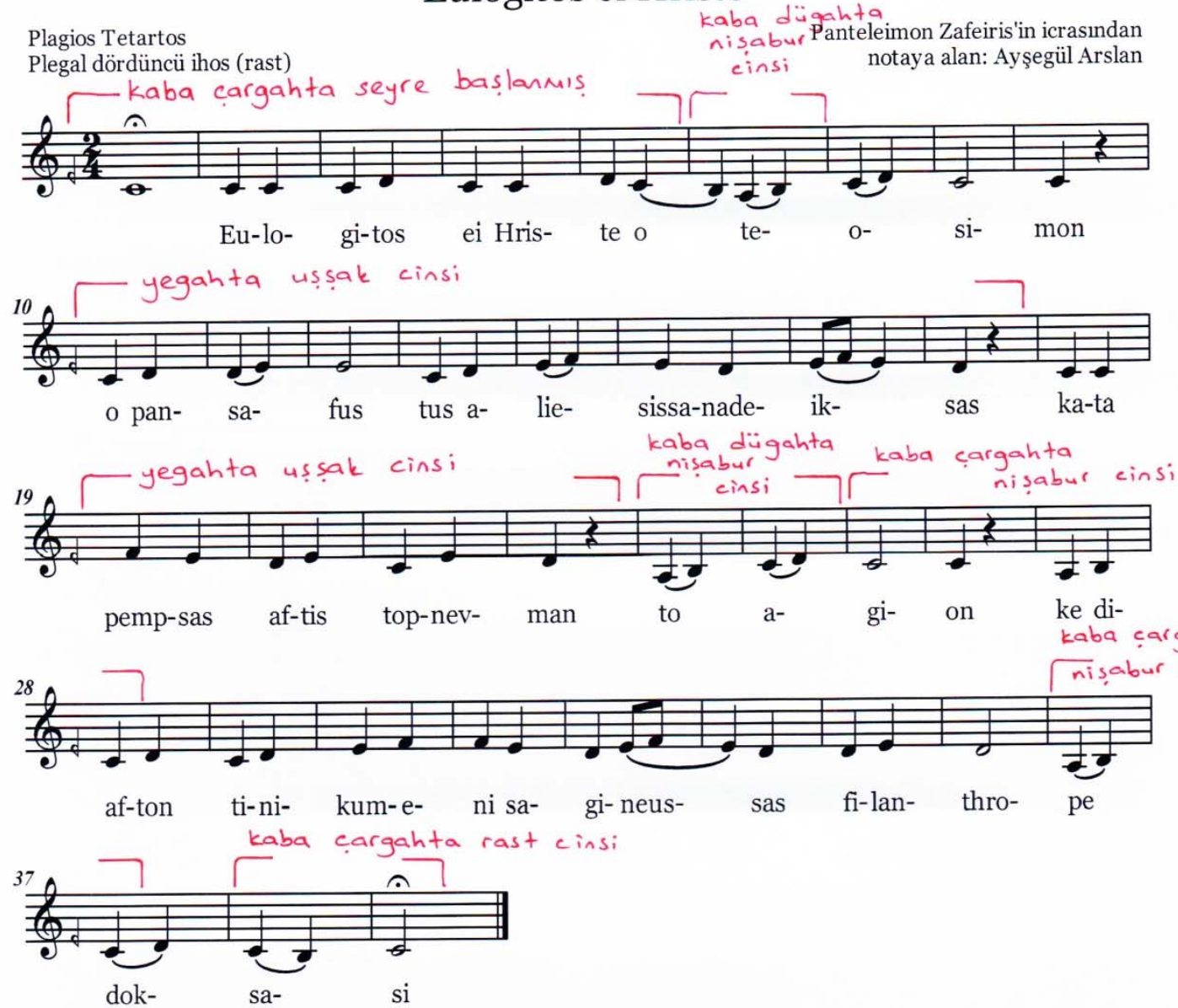
Ek 7

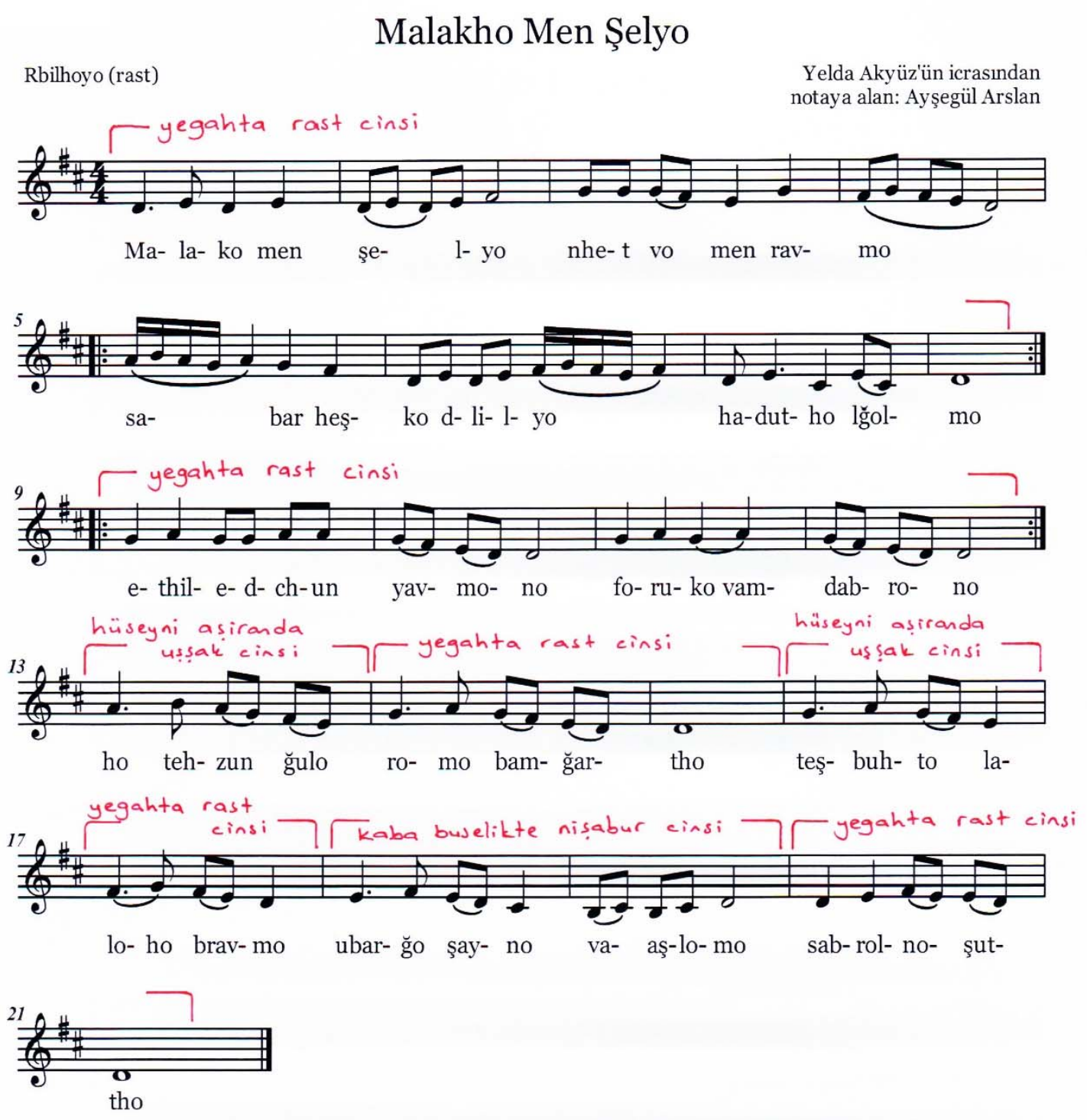


Ek 8

\section{Mşi'ho E’thi'led}

Trayono (hüseyni)

Yelda Akyüz'ün icrasindan notaya alan: Ayşegül Arslan
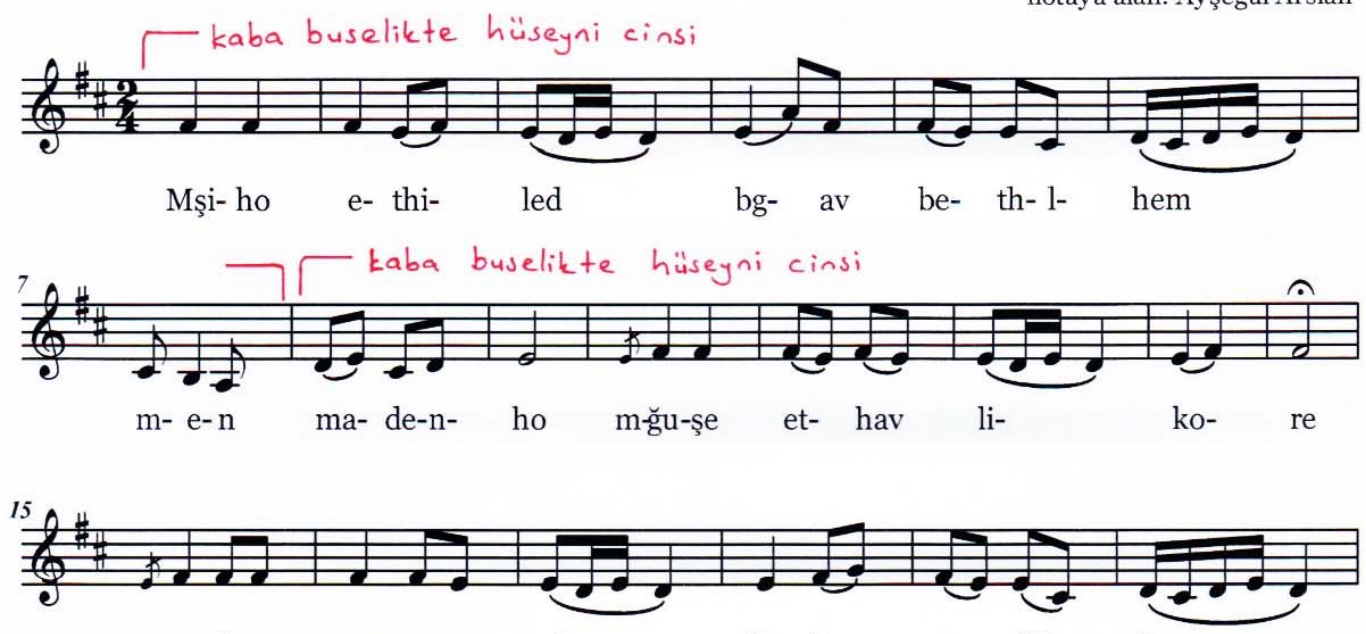

mşa- li-n vav vo-m- ri

day- ko

e- thiy-

le-
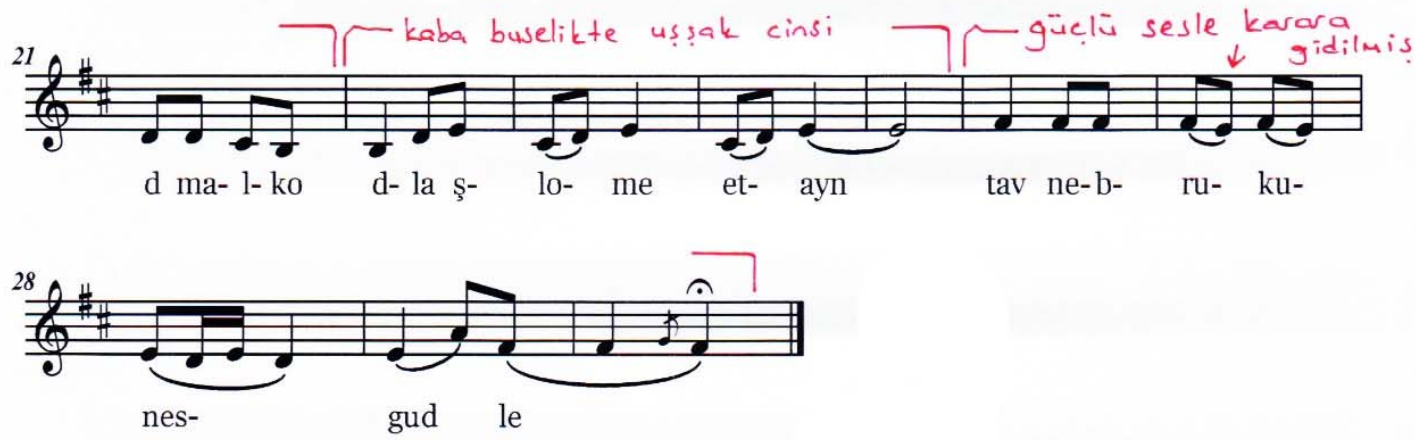
Ek 9

\section{Ho Roğem}

Rbilcoyo (rast)

Yelda Akyüz'ün icrasmnan notaya alan: Ayşegül Arslan

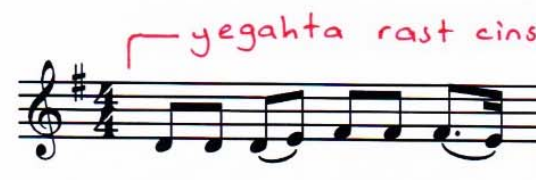

Ho ro- ğem bo-far- tho

kol had-vo fsi-ho

di-lid lam bam-ğar- tho

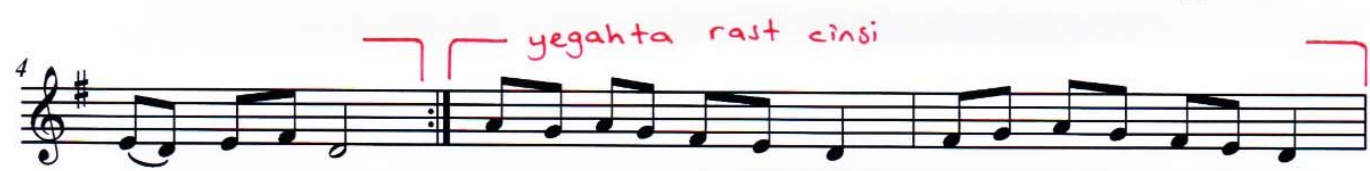

mor- yom-şi- ho

şub-ho la-lo- ho brav mo lar-ğo şay-no vaş-lo- mo

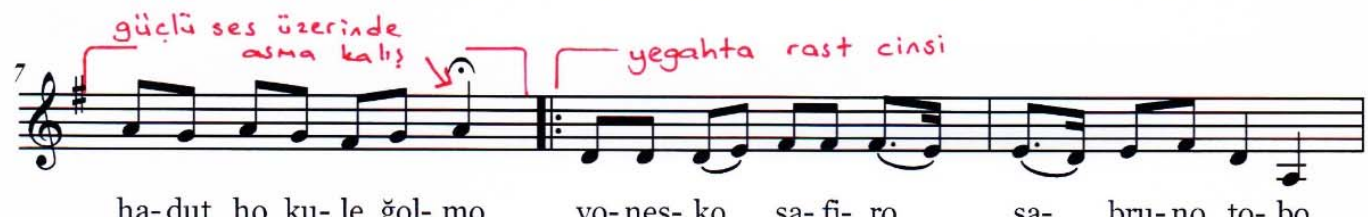

ha-dut ho ku- le ğol- mo

yo-nes- ko şa- fi- ro

şa- bru-no to- bo

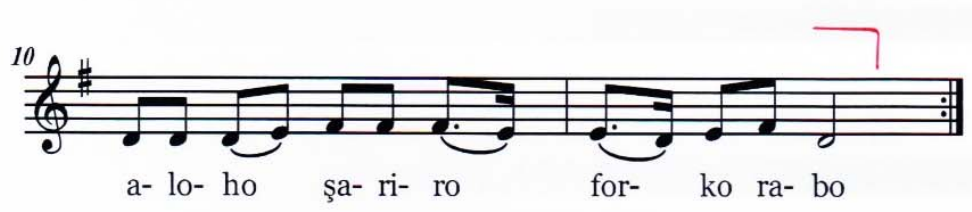


Ek 10

\section{Yavno Tlitho Thino Le}

Kadmoyo (uşşak)

kaba çargahta uș̣ak cinsi

Yelda Akyüz'ün icrasından notaya alan: Ayşegül Arslan
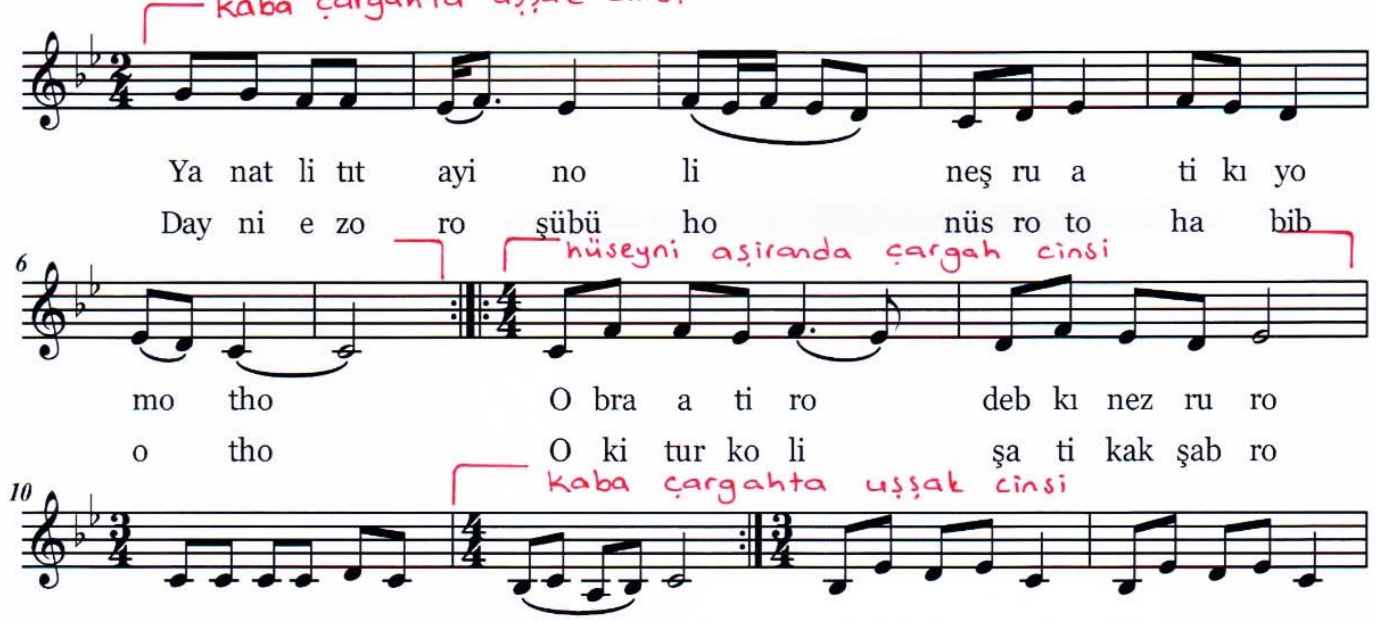

şva la ro kı te ki ra be Ke do no ren zi let re lak ro ve

$\mathrm{v}$ dı li me zi ma n lo

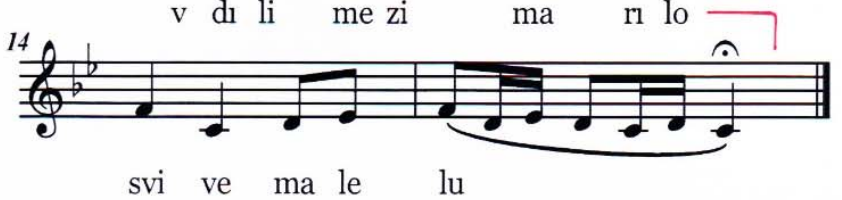


Ek 11

\section{Hdav Ğame Hdav Ğame}
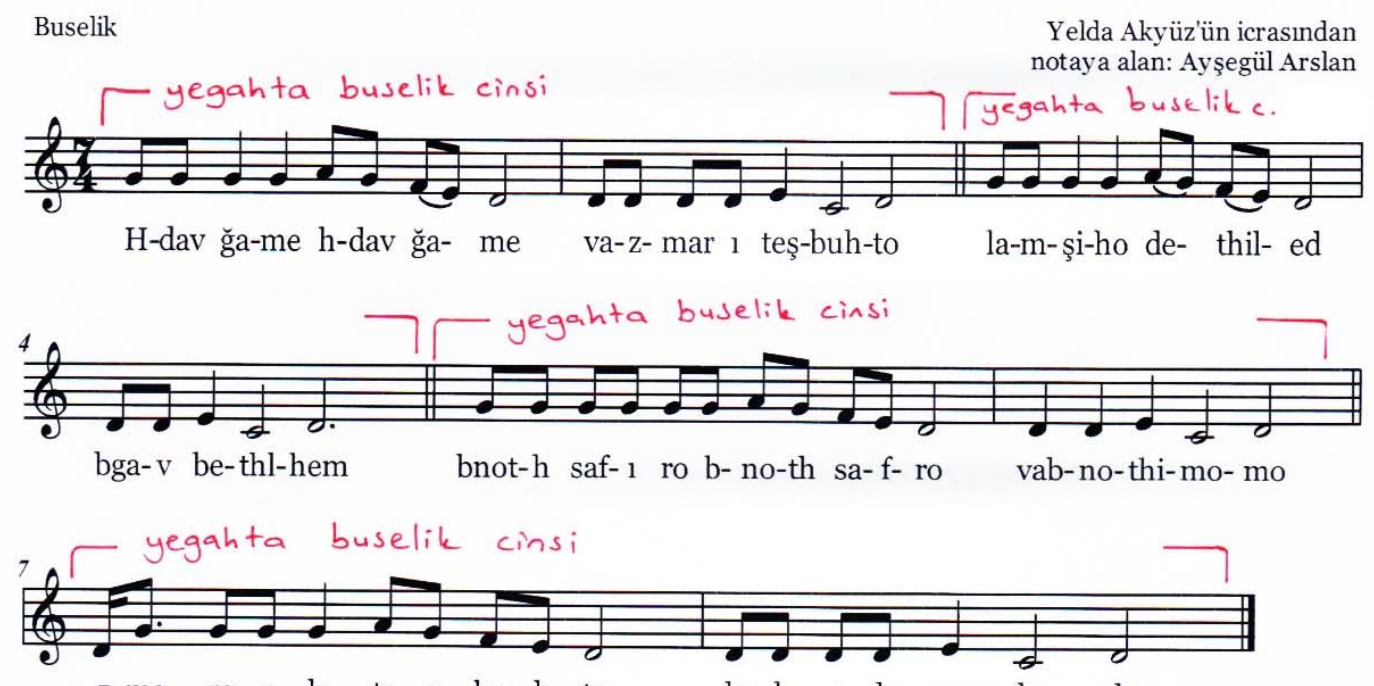

z-ma- re- $n$ le te- ş- bu- h- to la- b- ro b- mav- lo- de 